\title{
제2기 국가협력전략(CPS)에 근거한 KOICA 국별협력사업 중기(2017-2020) \\ 예산 연구 및 정책시사점*
}

목 차

I. 서론

II. CPS 기반 2017년 국별 예산 평가

1. 지역별 중점협력국 분석

2. 국가별 중점협력분야 분석

3. 목표달성 가능성에 따른 세부 국별 예산 분석

III. 목표달성을 위한 중기(2017-2020) 예산 산출 및 국별 분석

1. 산출방식

2. 목표달성 가능성 '낮음' 국가군

3. 목표달성 가능성 '매우 낮음' 국가군

IV. 결론 및 정책시사점

1. 제도 및 원조 거버넌스 개선 시사점

2. $\mathrm{KOICA}$ 사업 추진 시사점

참고문헌

* 동 연구는 2017년 제4회 KOICA 직원연구공모제(P2R) 수상작으로, 원고에 대해 아낌없는 조언과 격려를 주신 $\mathrm{KDI}$ 국 제정책대학원 이계우 교수님과 $\mathrm{KOICA}$ 아카데미 ODA연구원에 감사드린다. 


\section{요 약}

국별협력전략(Country Partnership Strategy, CPS)는 한국 정부의 최상위 국별 공적개발원조(Official Development Assistance, ODA) 지원전략으로, 2017년은 2016년 말 수립된 제2차 CPS의 성공적인 이행을 가늠하는 첫해라는 점에서 의미가 있다. 이 시점에서 본 연구는 KOICA의 2017년 예산을 토대로 $\mathrm{CPS}$ 이행상황을 분석하 고, 지역 및 섹터 예산 편성 관련 시사점을 도출하고자 하였다.

우선 지역별 분석 결과, 지역별 중점협력국 비중 및 예산 편성 간 비교적 연관성을 보였으나, 전체 사업 예산 대비, 중점협력국의 예산 비중은 목표치인 $70 \%$ 에 미치지 못하였다. 이어서 $\mathrm{KOICA}$ 사업이 $\mathrm{CPS}$ 중점협력분야를 얼마나 반영하고 있는지 분석 한 결과, 전체 중점협력국의 중점협력분야 예산 비중은 평균 $71 \%$ 로 목표치를 상회하였 으나, 24 개 중점협력국 중 12 개국(50\%)이 기준에 미달한다는 점을 발견하였다. 따라서 본 연구는 개선이 요구되는 12 개국을 대상으로 4개년(2017-2020) 예산 편성 시나리오 를 제시하였다.

끝으로 이 연구가 지닌 정책적 함의를 보다 의미 있게 활용하기 위해 KOICA의 자체적인 노력뿐만 아니라, 국내 ODA 거버넌스 전반에 대한 개선이 함께 진행되어야 한다는 점에서 내·외부적 시사점을 제시하였다.

주제어 : $\mathrm{CPS}$, 국별협력사업, 예산, 중점협력국 


\section{I. 서론}

2016년 12월, 국무조정실 산하 국제개발협력위원회는 제2차 중점협력대상국(24개국)에 대 한 국가협력전략(Country Partnership Strategy, 이하 CPS)을 최종 발표하였다. CPS는 우리나라의 원조전략과 협력대상국의 개발과제를 종합적으로 고려하여 지원 규모, 중점협력분 야 및 실행계획 등을 총체적으로 정리한 국가별 최상위 공적개발원조(Official Development Assistance, 이하 ODA) 지원전략 (이계우·박찬용, 2005)으로 2010년 경제협력개발기구 (Organization for Economic Cooperation and Development, 이하 OECD) 개발원조위원 회(Development Assistance Committee, 이하 DAC) 가입을 계기로 작성된 국내 최초 무. 유상 통합 CPS(2011-2015)에 이어 두 번째로 수립되었다.

이번 $\mathrm{CPS}$ 는 1 차에 대한 반성에 기초하여 보완 작성된 만큼 기존과 몇 가지 주요한 차이가 있다. 먼저 기존에는 $\mathrm{CPS}$ 내에 예산 지출과 관련된 목표가 포함되지 않아 $\mathrm{CPS}$ 가 실제 사업 추진을 위한 예산 편성 계획과 연동되지 못했다(OECD, 2012). 따라서 1 기 $\mathrm{CPS}$ 가 해당 중점협 력국에 대한 원조에 더 큰 관심을 기울이겠다는 선언적 의미가 컸다면, 2 기 $\mathrm{CPS}$ 에서는 $\mathrm{OECD}$ 동료검토의 제언을 받아들여 CPS 기간 동안 국가 및 중점분야별로 예산 계획을 수립하였다는 점이 중요한 변화이다. 또한, 전체 $\mathrm{CPS}$ 마다 총 지원 금액의 최소 $70 \%$ 이상을 중점협력분야에 지원하겠다고 명시적으로 약속한바, 예산 편성 과정에서 CPS가 우선적인 고려요소로 새롭게 대두하였다.

두 번째로 주목할 만한 차이점은 중점협력 대상국이 기존 26 개국에서 24 개국으로 감소하였 다는 사실이다. 아직 한국의 ODA 규모가 국제적인 수준에 미치지 못한다는 사실1)을 고려할 때, 이는 긍정적인 변화이다. 한국의 지원이 절실한 일부 개발도상국을 선별적으로 지원함으로 써 한정된 역량과 재원을 집중하고, 국제개발협력의 효과성을 제고하는 방편이 될 수 있기 때문이다.

사실 1 기 $\mathrm{CPS}$ 의 경우, 이행 시작 시점을 훌쩍 넘기고 비로소 작성되었다. 최초 베트남, 가나, 솔로몬군도 등 3개국에 대한 CPS가 제도 시행 첫해인 2011년 8월에 수립되었고, 2012년 에는 볼리비아, 스리랑카, 인도네시아, 몽골, 아제르바이잔, 에티오피아, DR콩고, 캄보디아, 방 글라데시, 필리핀, 우즈베키스탄 등 11개국에 대한 CPS 수립이 완료되었다. 끝으로 2013년 8월, 나머지 12 개국 (라오스, 모잠비크, 페루, 카메룬, 콜롬비아, 나이지리아, 네팔, 동티모르,

1) 2016년 기준 $\mathrm{OECD}$ 통계에 따르면, 한국의 ODA 공여 금액은 19.6 억불로 전체 $\mathrm{OECD} \mathrm{DAC} 29$ 개국 중 16 위를 차지하였다. 이는 $\mathrm{DAC}$ 평균 49 억불 대비 $40 \%$ 수준으로 평균의 절반에도 미치지 못하는 수치이다. 
르완다, 우간다, 파라과이, 파키스탄)에 대한 전략 수립이 가까스로 완성되었다 (국제개발협력 위원회, 2014b). 결국, 전체 CPS의 절반 가까운 46\%가 2013년 하반기에 수립되었고, 이렇게 만들어진 $\mathrm{CPS}$ 는 실상 1 년 반 만에 종료되어 국가협력전략의 의의를 충분히 살리지 못했다.

마지막으로 1 기 $\mathrm{CPS}$ 의 가장 근본적인 문제는 바로 $\mathrm{CPS}$ 가 해당 수원국에 대한 최상위 지원 전략임에도 불구하고, 실제 $\mathrm{ODA}$ 수행기관에 미치는 구속력과 영향력은 미미했다는 점이다 (국제개발협력평가소위원회, 2015).

2017년도는 이러한 점들을 보완하여 수립된 제 2 기 CPS의 성공적 이행을 가늠하는 첫해라는 면에서 의미가 있다. 제2차 ODA 기본계획(2016-2020)과 CPS를 통해 중점협력국에 대한 지원 확대 방침이 구체화되었고, 양자 원조의 최소 $70 \%$ 이상을 중점프로그램에 집중하겠다는 한국 정부의 의지가 드러난 만큼, 이번 2기 CPS는 국별사업 예산 편성, 심의, 배정에 있어서 중요한 가이드라인으로 기능해야 할 것이다.

이러한 맥락에서 본고는 한국의 무상원조전담기관인 한국국제협력단(Korea International Cooperation Agency, 이하 KOICA) 국별협력사업 예산을 토대로 2017년 예산2)이 CPS와 얼마나 밀접하게 연관이 있는지 살펴보고, 그 결과를 토대로 향후 지역 및 섹터 예산 편성 관련 시사점을 도출하고자 한다.

기존에도 CPS 관련 논의는 일부 진행되어왔다. 하지만 국내 연구의 초점은 주로 CPS 수립을 위한 선진국 사례 연구 (김세원·김종섭·이영섭, 2013), CPS 수립과정 분석 (정유아, 2010), $\mathrm{CPS}$ 세부 내용에 대한 평가 (경희대학교, 2015) 등에 집중되었으며, 동시에 정성적인 분석 위주로 이루어졌다. 반면, 본 연구는 $\mathrm{KOICA}$ 의 예산 분석을 통해 상위 정책문서인 $\mathrm{CPS}$ 와의 연계성을 정량적으로 점검하고, 구체적인 예산 배분 목표 달성을 위한 기준을 제시한다는 점에 서 선행연구와 차별화된다.

물론 예산 편성 및 운영의 다양한 측면을 고려할 때, $\mathrm{CPS}$ 만이 절대적인 ODA 재원 배분의 기준일 수는 없으나, 한국이 국제사회와 한 명시적인 약속이라는 점에서 지역별, 국가별로 전체 국가 사업 예산 대비, 중점협력국의 KOICA 예산 비중을 비교해보는 것은 의미가 있다고 보인 다. 그 결과는 $\mathrm{KOICA}$ 가 다양한 협력대상국 중 중점협력국가에 얼마나 각별한 관심을 기울이고 있는지 파악할 수 있는 근거가 되기 때문이다.

2) 제 2기 CPS는 2016년 말 공식적으로 발표되었다는 점에서 동 연구가 2017년 예산을 토대로 하는 것에 대한 일부 비판이 있을 수 있으나, 실제 중점협력 24개국은 2015년 3월 기 확정되었으며, 본 연구의 목적이 과거 실적에 대한 평가 자체보다 현황 분석을 토대로 제2기 CPS 종료 시점에 성공적으로 목표를 달성할 수 있도록 가이드라인을 제시하는데 방점이 있다는 점에서 분석 대상을 선정하였다. 
이어서, 본 연구는 개별 $\mathrm{CPS}$ 마다 지정된 3 개 내외의 국가별 중점협력분야에 주목하였다. $\mathrm{KOICA}$ 가 수행하고 있는 다양한 협력사업이 CPS상 중점협력분야와 일치하는지를 세부적으 로 분석하고, 그 결과를 바탕으로 국가를 4 단계로 분류하여 국가별 진단을 실시하고자 한다. 진단 결과만으로도 향후, KOICA 사업의 국가별 투입(input) 평가를 위한 계량지표를 제시한 다는 점에서 의의가 있다. 그러나 이 연구가 지닌 정책적 함의를 보다 의미 있게 활용하기 위해서는 $\mathrm{KOICA}$ 의 자체적인 노력도 중요하지만, 현행 원조예산 편성 시스템 등 국내 ODA 거버넌스 전반에 대한 개선이 동반되어야 한다는 점에서 정책적 제언을 결론에 포함하고자 한다. 


\section{CPS 기반 2017년 국별 예산 평가}

\section{1. 지역별 중점협력국 분석}

\section{1) $1 \cdot 2$ 기 중점협력국 현황}

<표 $1>$ 은 $1 \cdot 2$ 기에 걸쳐 한국의 중점협력국 선정이 어떻게 변화하였는지를 한눈에 볼 수 있는 자료이다. 가장 큰 변화는 앞서 설명된 바와 같이 종전 26 개국이었던 중점협력국 수가 24 개로 축소되었다는 점과 원조 소외국 배려차원에서 1 기에 포함되었던 태평양 도서국가인 솔로몬 군도가 제외되었다는 점을 꼽을 수 있다. 마찬가지로 아시아에서는 동티모르, 아프리카 에서는 카메룬, $\mathrm{DR}$ 콩고, 나이지리아가 각각 2기 $\mathrm{CPS}$ 에서 제외되었다. 반면, 2 기 $\mathrm{CPS}$ 에 새롭 게 등장한 국가들은 아시아의 미얀마, 아프리카의 세네갈 및 탄자니아 이상 3 개국이다.

1,2 기 중점협력국 지정 현황을 비교해 볼 때, 전반적으로 $1 \cdot 2$ 기 간 지역별 중점협력국 지정 비중은 유사하며, 1 기 중점협력대상국 $83 \%$ (20개국)가 2기에서도 중점협력국의 지위를 그대로 유지하였기 때문에 큰 변화는 없었다고 평가할 수 있다.

〈표 1〉1 - 2기 중점협력국 지정 현황

\begin{tabular}{|c|c|c|c|}
\hline 지역 & 해당 국가 & 1기 (2010-2015) & 2기 (2016-2020) \\
\hline \multirow[b]{6}{*}{ 아시아 } & 네팔 & 0 & 0 \\
\hline & 라오스 & o & o \\
\hline & 동티모르 & o & \\
\hline & 몽골 & o & o \\
\hline & 미얀마 & & o \\
\hline & 방글라데시 & o & o \\
\hline \multirow{6}{*}{ 아시아 } & 베트남 & 0 & o \\
\hline & 스리랑카 & o & o \\
\hline & 인도네시아 & $\mathrm{o}$ & o \\
\hline & 캄보디아 & 0 & o \\
\hline & 파키스탄 & o & o \\
\hline & 필리핀 & o & o \\
\hline \multicolumn{2}{|c|}{ 아시아 소계 } & 11 & 11 \\
\hline \multirow{3}{*}{ 아프리카 } & 가나 & o & o \\
\hline & 르완다 & o & o \\
\hline & 모잠비크 & 0 & 0 \\
\hline
\end{tabular}




\begin{tabular}{|c|c|c|c|}
\hline \multirow[t]{8}{*}{ 지역 } & 해당 국가 & 1기 (2010-2015) & 2기 (2016-2020) \\
\hline & 세네갈 & & o \\
\hline & 에티오피아 & o & $\mathrm{o}$ \\
\hline & 우간다 & o & 0 \\
\hline & 탄자니아 & & o \\
\hline & 카메룬 & o & \\
\hline & DR콩고 & o & \\
\hline & 나이지리아 & o & \\
\hline \multicolumn{2}{|c|}{ 아프리카 소계 } & 8 & 7 \\
\hline \multirow{4}{*}{ 중남미 } & 볼리비아 & o & o \\
\hline & 콜롬비아 & 0 & 0 \\
\hline & 파라과이 & 0 & $\mathrm{o}$ \\
\hline & 페루 & 0 & 0 \\
\hline \multicolumn{2}{|c|}{ 중남미 소계 } & 4 & 4 \\
\hline \multirow{2}{*}{$\begin{array}{c}\text { 중동 } \\
\text { 중앙아 }\end{array}$} & 아제르바이잔 & 0 & o \\
\hline & 우즈베키스탄 & o & o \\
\hline \multicolumn{2}{|c|}{ 중동·중앙아 소계 } & 2 & 2 \\
\hline 태평양 & 솔로몬군도 & 0 & \\
\hline \multicolumn{2}{|c|}{ 태평양 도서국 소계 } & 1 & 0 \\
\hline \multicolumn{2}{|c|}{ 총 계 } & 26 & 24 \\
\hline
\end{tabular}

출처: 국가별 $\mathrm{CPS}$ 를 바탕으로 저자 재구성

$\mathrm{KOICA}$ 를 포함한 다양한 국내 ODA 수행기관들은 수원국과의 관계 또는 현재 진행 중이거 나 향후 계획 중인 사업 등에 따라 각자 다른 국가를 선호할 수 있다. 따라서 많은 개발도상국 중 특정 국가를 중점협력국으로 선정했다는 사실은 쉽지 않은 논의의 결과물이라 볼 수 있다. 중점협력국 여부는 향후 ODA 예산 편성에 있어 명시적 혹은 묵시적 기준이 되기 때문이다. 따라서 중점협력국 선정은 곧 향후 최소 5 년, 또는 그 이상 지속될 ODA 예산의 방향성을 결정하는 마일스톤이 된다.

\section{2) 지역별 중점협력국 예산 평가}

$\mathrm{KOICA}$ 의 2017년도 국별 예산 총액은 3,355억 원이며, 이는 전체 출연금의 $51.3 \%$ 에 달하는 규모이다. 지역별로 우선 아시아태평양 3 ) 지역원조는 1,354억 원(40\%)으로 4 개 지역 중 가장

3) $\mathrm{KOICA}$ 예산 분류 방식을 따라, 중동을 제외한 아시아 (동아시아 및 서남아시아)와 태평양 도서국을 구분하지 않고 아시아태평양으로 묶어서 표기하였다. 
큰 비중을 차지한다. 이어서 아프리카는 1,231 억 원으로 예산의 $37 \%$ 를 차지하며, 중남미와 중동·중앙아 지역 예산은 큰 차이가 없으나, 중동·중앙아가 389억 원(12\%)으로 약간 많고, 중남미는 380 억 원(11\%)으로 가장 적은 예산을 할당받았다. 주목할 점은 아프리카 지역원조가 2016년 대비, 181억 원이 증가(17.3\%)하여 매우 가파른 성장세를 나타내었다는 점이다 (한국 국제협력단, 2017). 이러한 KOICA의 예산 편성 기조는 아시아 중심 지원 기조를 유지하되, 아프리카의 비중을 점진적으로 확대하겠다는 제 2 차 국제개발협력계획 (국제개발협력위원회, 2015)과도 일맥상통한다.

국내에서 아직 명시적으로 $\mathrm{CPS}$ 와 지역별 예산 배분의 관계를 언급한 전략문서가 없음에도 불구하고, <표 $1>$ 에서 확인하였듯 $1 \cdot 2$ 기 대륙별 중점협력국가 수가 거의 동일하게 유지되었다 는 사실은 지역별 중점협력국 배분이 정치·외교적, 개발 수요 등을 다각도로 고려한 결과임을 추론할 수 있다.

〈그림 1〉 CPS에 근거한 2017년 지역별 중점협력국 예산 비교

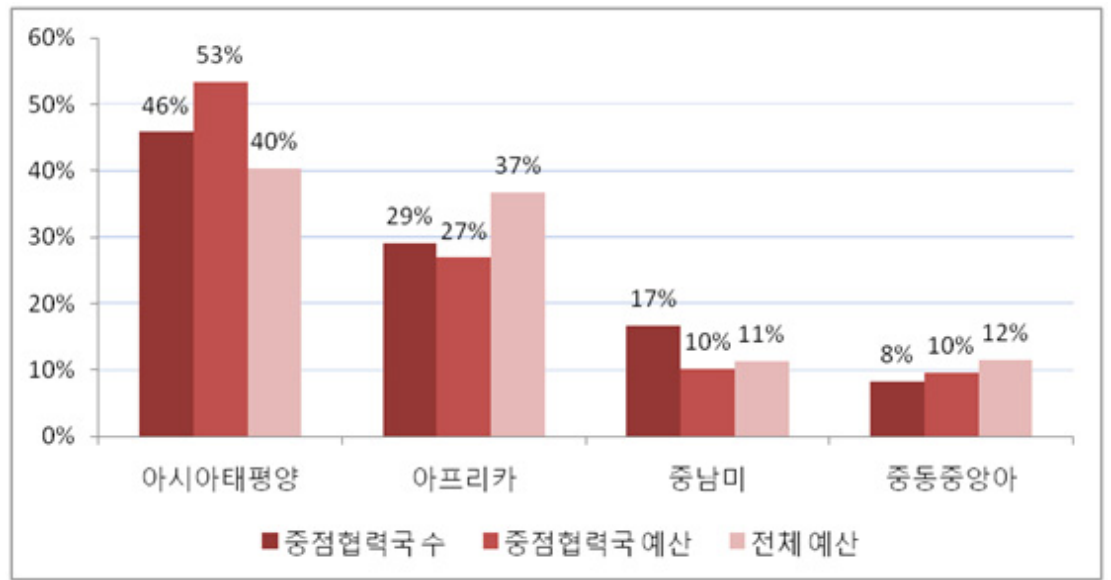

출처: 국가별 CPS 및 KOICA 예산안을 바탕으로 저자 재구성

그러나 세부적으로 살펴보면 같은 중점협력국이라 해도 지역에 따라 상대적인 예산 비중에 차이가 있음을 확인하게 된다. 즉, 동일하게 중점협력국으로 지정되었다 해도 타 지역 대비 아시아에 속한 중점협력국들은 더 많은 사업 예산을 받는 경향이 있다. 이와 달리 중남미 지역의 경우, 중점협력국 수 대비, 상대적으로 중점협력국 예산이 과소하게 책정되어 있다. 특히 중점협 력국 수를 감안하면 중동·중앙아 지역 대비, 두 배 이상의 예산이 지원이 기대되나, 두 지역 간 중점협력국 예산은 거의 차이가 없고, 전체 예산의 경우, 오히려 중동·중앙아 지역이 더 많은 예산을 지원받았음을 <그림 $1>$ 에서 발견하게 된다. 이 사실을 역으로 생각해보면, 향후 중남미 지역에서 중점협력국과의 협력사업이 보다 확대되어야 하며, 예산 규모도 이에 걸맞게 
늘어날 필요가 있다는 결론을 도출할 수 있다. 한편, 아프리카 지역은 중점협력국 수 대비, 전체 지역 예산 규모가 크다. 이는 $\mathrm{KOICA}$ 가 중점협력국에 집중하기보다 다수의 국가에 다양한 지원을 하고 있다는 증거이며, 그 배경에 대해서는 아래 <표 $2>$ 에서 다시 한번 짚어보고자 한다. 끝으로 중동·중앙아의 경우, 아프리카와 마찬가지로 지역의 중점협력국 수 대비 지역 예산 비중은 크지만, 차이가 미미하여 2기 CPS 지역 배분이 예산 편성과 비교적 일치하는 지역이라 할 수 있다.

〈표 2〉 2017년 지역별 중점협력국 예산 분석

(단위: 백만 원, \%)

\begin{tabular}{l|c|c|c|c}
\hline \multicolumn{1}{c|}{ 지역 } & $\begin{array}{c}\text { 중점협력국 } \\
(\mathrm{A})\end{array}$ & $\begin{array}{c}\text { 중점협력국 외 } \\
(\mathrm{B})\end{array}$ & $\begin{array}{c}\text { 전체 예산 } \\
(\mathrm{A}+\mathrm{B})\end{array}$ & $\begin{array}{c}\text { 중점협력국 } \\
\text { 비중(A/(A+B)) }\end{array}$ \\
\hline 아시아태평양 & $112,111(53)$ & $23,277(19)$ & $135,388(40)$ & $83 \%$ \\
\hline 아프리카 & $56,555(27)$ & $66,563(53)$ & $123,118(37)$ & $46 \%$ \\
\hline 중남미 & $21,374(10)$ & $16,666(13)$ & $38,040(11)$ & $56 \%$ \\
\hline 중동· 중앙아 & $20,107(10)$ & $18,819(15)$ & $38,926(12)$ & $52 \%$ \\
\hline \multicolumn{1}{c|}{ 계 } & 210,147 & 125,325 & 335,472 & $63 \%$ \\
\hline
\end{tabular}

출처: 국가별 CPS 및 KOICA 예산안을 바탕으로 저자 재구성

<표 2>는 지역별 예산을 중점협력국 예산과 중점협력국 외 국가 예산으로 구분하였다. 아시 아태평양 지역은 중점협력국 예산 비중이 $83 \%$ 로 목표인 $70 \%$ 를 상회한다. 반대로 아프리카 지역에서 중점협력국 예산이 차지하는 비중은 $46 \%$ 에 불과하다. 이 지역에는 기존 중점협력국 이었다가 2016년에 제외된 3개국 (현재는 비중점국인 나이지리아, 카메룬, DR콩고)이 있어, 중점협력국이던 당시 신규 프로젝트가 다수 착수되었을 것으로 판단된다. 결과적으로 해당 국가의 지위는 비중점협력국으로 바뀌었다 해도, 진행 중인 협력사업을 갑작스럽게 축소하기는 어려운바 이에 따른 예산 감축도 쉽지 않았으리라 예측해 볼 수 있다. 그럼에도 아프리카 지역에 배분된 한정된 예산하에서 효과적으로 2 기 중점협력국을 지원하기 위해 중점협력대상 제외국에 대한 지원 비중은 점차 축소되는 것이 바람직할 것이다.

중남미와 중동·중앙아 지역의 전체 예산 대비 중점협력국 지원 비중 역시 각각 $56 \%, 52 \%$ 로 높지 않다. 이들 지역은 아시아, 아프리카 지역 대비 상대적으로 중점협력국으로 지정된 국가 수가 적다. 반면, $\mathrm{KOICA}$ 는 통합 $\mathrm{CPS}$ 수립 이전부터 중남미 및 중동·중앙아 지역에서 다수 지역에 $\mathrm{KOICA}$ 사무소를 설치하는 등4) 활발하게 사업을 수행해왔다. 이 때문에 비록 정책적인

4) 중동·중앙아 지역사무소는 우즈베키스탄, 아제르바이잔, 이라크, 팔레스타인, 요르단, 키르기스스탄 이상 6개국이며, 중남미지역 사무소는 파라과이, 페루, 콜롬비아, 볼리비아, 과테말라, 에콰도르, 엘살바도르, 도미니카 이상 8개국 총 
판단에 의해 중점협력국으로 지정되지는 못했으나, $\mathrm{KOICA}$ 입장에서 여전히 중요한 협력국으 로 여겨지는 국가가 다수 있고, 이러한 비중점협력국에 예산을 나누어 배정하다 보니, 상대적으 로 중점협력국 예산 비중이 낮아진 것으로 보인다.

〈그림 2〉 2017년 지역별 중점협력국 예산 비교

(단위: 백만 원)

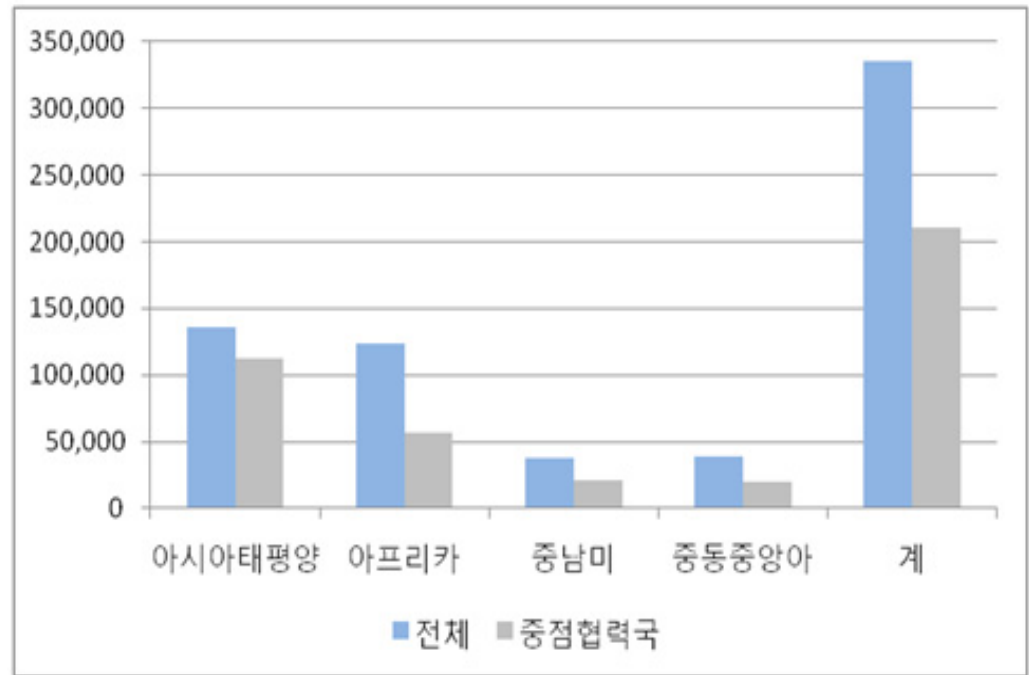

출처: 국가별 CPS 및 KOICA 예산안을 바탕으로 저자 재구성

종합적으로 살펴보면 전체 국가별 사업 예산 중 중점협력국에 편성되는 예산은 $63 \%$ 로 목표 치인 70\%에는 미치지 못했음을 알 수 있다. 특히, 아시아태평양을 제외한 전체 지역에서 중점협 력국이 차지하는 예산 비중이 $60 \%$ 미만으로 나타나 전반적인 개선 노력이 요구된다. 물론 앞서 언급한 것처럼 비중점국가에서 진행 중인 사업을 갑자기 중단하거나, 관련 예산을 삭감하 는 것은 수원국과의 관계나 사업의 효과성 등의 측면을 고려할 때, 단기간에 해결할 수 있는 문제는 아니다. 다만, 중점협력국 지정이 한국의 한정된 자원을 보다 효과적으로 분배하려는 국가적인 정책 방향이라는 점에서 구체적인 예산상 노력이 뒷받침되어야 한다는 점을 기억해야 할 것이다. 


\section{2. 국가별 중점협력분야 분석}

\section{1) 중점협력분야 현황}

전반적으로 보면 CPS상 국가별 중점협력분야는 3개 내외로 구성되었다. 한데 묶인 유사 분야를 구분5)해도, 최대 6 개 분야 (세네갈)로 제한되어 있다. 이는 비교우위를 갖는 소수 분야에 집중해서 특정 국가의 개발목표를 집중적으로 지원하겠다는 한국 정부의 의지라고 해석할 수 있다.

〈표 3〉 제2기 중점협력국별 중점협력분야 선정 현황

\begin{tabular}{|c|c|c|}
\hline 국가 & 중점협력분야 & 분야 수 \\
\hline 네팔 & 교육, 물관리 및 보건위생, 에너지, 지역개발 & 4 \\
\hline 라오스 & 물관리 및 보건위생, 에너지, 교육, 지역개발 & 4 \\
\hline 몽골 & 교육, 물관리 및 보건위생, 공공행정, 교통 & 4 \\
\hline 미얀마 & 교통, 에너지, 공공행정, 지역개발 & 4 \\
\hline 방글라데시 & 교육, 물 관리 및 보건위생, 통신, 교통 & 4 \\
\hline 베트남 & 교통, 교육, 물관리 및 보건위생, 공공행정 & 4 \\
\hline 스리랑카 & 교육, 교통, 물관리, 지역개발 & 4 \\
\hline 인도네시아 & 교통, 공공행정, 환경보호, 물관리 & 4 \\
\hline 캄보디아 & 교육, 지역개발, 교통, 물관리 및 보건위생 & 4 \\
\hline 파키스탄 & 물관리 및 보건위생, 에너지, 교통, 지역개발 & 4 \\
\hline 필리핀 & 교통, 물관리 및 보건위생, 지역개발, 재해예방 & 4 \\
\hline 가나 & 보건, 교육, 에너지, 지역개발 & 4 \\
\hline 르완다 & 교육, 통신, 지역개발 & 3 \\
\hline 모잠비크 & 교통, 에너지, 물관리 및 보건위생, 교육 & 4 \\
\hline 세네갈 & 물관리 및 보건위생, 지역개발 및 수산업, 교육, 교통 & 4 \\
\hline 에티오피아 & 물관리 및 보건위생, 지역개발, 에너지, 교통 & 4 \\
\hline 우간다 & 보건, 교육, 지역개발 & 4 \\
\hline 탄자니아 & 물관리 및 보건위생, 교육, 교통, 에너지 & 4 \\
\hline 볼리비아 & 보건, 교통, 에너지, 지역개발 & 4 \\
\hline 콜롬비아 & 지역개발, 평화구축, 교통, 산업 & 4 \\
\hline 파라과이 & 물관리 및 보건위생, 교통, 지역개발, 통신 & 4 \\
\hline 페루 & 보건, 공공행정, 환경보호, 교통 & 4 \\
\hline 아제르바이잔 & 통신, 물관리 및 보건위생, 공공행정, 지역개발 & 4 \\
\hline 우즈베키스탄 & 교육, 물관리 및 보건위생, 공공행정 & 3 \\
\hline
\end{tabular}

출처: 국가별 $\mathrm{CPS}$ 를 바탕으로 저자 재구성

5) 예: 물관리 및 보건위생을 각각 물관리 분야와 보건위생 분야로 분류 
<표 3>을 분야 중심으로 재편한 표는 아래와 같다. 한국의 중점협력분야는 총 13 개로 $\mathrm{KOICA}$ 의 5 대 분야 (교육, 보건의료, 공공행정, 농림수산, 기술환경에너지)와는 일부 겹치지만 대체로 $\mathrm{CPS}$ 의 중점협력분야가 더 세부적인 분야를 다루고 있다. 예를 들어, 물관리 및 보건위생 은 보건의료영역과 기술환경에너지 중 수자원 분야를 합친 영역이며, 교통, 에너지, 산업, 환경보 호 등은 모두 기술환경에너지의 하위항목으로 분류 가능하다. 재해예방의 경우, 범분야의 하위항 목인 기후변화로 주로 분류되나, 기술환경에너지의 하위항목으로도 볼 수 있다. 마찬가지로 통신 또한 범분야 하위항목인 정보통신기술(Information and Communication Technology, ICT) 로 포함할 수 있으나, 대부분의 통신사업이 전자정부와 연관 깊다는 점에서 공공행정으로도 분류 가능하다. 한편, 중점협력분야 상 지역개발(또는 지역개발 및 수산업)로 표현된 사업의 경우, 농림수산에 상응한다고 간주하기 쉽다. 그러나 엄밀히 말하자면 농림수산분야에서도 단순 한 인프라 및 연구개발(Research and Development, R\&D) 사업을 제외하고, 지역주민 역량 강화, 기술전수 등 지역 개발(rural development)적 요소가 포함된 경우에만 동 중점협력분야 로 분류하는 것이 타당할 것으로 보인다. 마찬가지로 평화구축 분야의 경우 $\mathrm{KOICA}$ 의 공공행정 분야의 하위항목으로 분류할 수 있지만, $\mathrm{CPS}$ 세부항목이 평화와 직결되는 분쟁지역 및 무장해 제 반군 관련 활동으로 제한되고 있다는 점에서 일반적인 공공행정과 구분하여 별도 분야로 분류하고자 한다.

〈표 4〉 KOICA 5대 분야와 CPS 중점협력분야의 상관관계

\begin{tabular}{l|l|c}
\hline \multicolumn{1}{c|}{ KOICA 5대 분야 } & \multicolumn{1}{|c}{ CPS 중점협력분야 } & 분야 수 \\
\hline 교육 & 교육 & 1 \\
\hline 보건의료 & 보건위생 & 1 \\
\hline 공공행정 & 공공행정, 통신, 평화구축, 산업 & 4 \\
\hline 농림수산 & 지역개발, 수산업 & 2 \\
\hline 기술환경에너지 & 물관리, 에너지, 교통, 환경보호, 재해예방 & 5 \\
\hline & & 13 \\
\hline
\end{tabular}

출처: 국가별 $\mathrm{CPS}$ 를 바탕으로 저자 재구성

<표 4>에서 확인할 수 있듯이 $\mathrm{KOICA}$ 의 5 대 분야는 $\mathrm{CPS}$ 중점분야 대비 훨씬 다양한 분야를 폭넓게 아우르고 있음을 알 수 있다. 다만 본 연구의 경우, $\mathrm{KOICA}$ 를 분석 대상으로 하지만, 분석의 기준이 $\mathrm{CPS}$ 를 기반으로 한다는 점에서 $\mathrm{CPS}$ 의 중점협력분야를 따라 연구를 수행하였음을 밝혀둔다. 
〈표 5〉 중점협력분야별 국가 현황

\begin{tabular}{|c|c|c|c|c|}
\hline & & 중점협력분야 & 국가 수 (A) & 비율 (A/B) \\
\hline \multirow{4}{*}{1} & \multirow{4}{*}{ 물관리 및 보건위생 } & 소계 & 21 & $88 \%$ \\
\hline & & 물관리 및 보건위생 & 15 & $63 \%$ \\
\hline & & 보건만 포함 & 4 & $17 \%$ \\
\hline & & 물관리만 포함 & 2 & $8 \%$ \\
\hline 2 & \multicolumn{2}{|l|}{ 교통 } & 17 & $71 \%$ \\
\hline \multirow{3}{*}{3} & \multirow{3}{*}{ 지역개발 } & 소계 & 16 & $67 \%$ \\
\hline & & 지역개발만 포함 & 15 & $63 \%$ \\
\hline & & 지역개발 및 수산업 & 1 & $4 \%$ \\
\hline 4 & \multicolumn{2}{|l|}{ 교육 } & 14 & $58 \%$ \\
\hline 5 & \multicolumn{2}{|l|}{ 에너지 } & 9 & $38 \%$ \\
\hline 6 & \multicolumn{2}{|l|}{ 공공행정 } & 7 & $29 \%$ \\
\hline 7 & \multicolumn{2}{|l|}{ 통신 } & 4 & $17 \%$ \\
\hline 8 & \multicolumn{2}{|l|}{ 환경보호 } & 2 & $8 \%$ \\
\hline 9 & \multicolumn{2}{|l|}{ 재해예방 } & 1 & $4 \%$ \\
\hline 10 & \multicolumn{2}{|l|}{ 평화구축 } & 1 & $4 \%$ \\
\hline 11 & \multicolumn{2}{|l|}{ 산업 } & 1 & $4 \%$ \\
\hline & \multicolumn{2}{|l|}{ 전체 중점협력국6) (B) } & 24 & $100 \%$ \\
\hline
\end{tabular}

출처: 국가별 $\mathrm{CPS}$ 를 바탕으로 저자 재구성

위의 표에 의하면, 물관리 및 보건위생을 중점분야로 선택한 국가는 24 개국 중 21 개국(88\%) 으로 가장 높은 비율을 차지한다. 중점분야로 보건과 물관리 중 일부만 선택한 국가도 있었으나, 각각 4 개국, 2 개국에 불과하여 보건과 물관리는 상호 높은 연관성이 있음을 예측할 수 있다. 다음으로 교통으로 17 개국( $71 \%)$ 에서 선택되었으며, 지역개발은 총 16 개 국가(67\%)가 중점분 야로 선택하였는데, 세네갈의 경우는 지역개발과 함께 수산업이 추가되었다. 한편, 교육 분야는 14 개국(58\%) 즉, 과반수 국가에서 선택되었으며, 그 밖에 소수 분야로 에너지(9개국, $38 \%)$, 공공행정(7개국, $29 \%$ ), 통신(4개국, $17 \%$ ), 환경보호(2개국, $8 \%$ )이 있다. 한편, 개별 국가의 특수성이 반영된 분야로는 필리핀의 재해예방 분야, 콜롬비아의 평화구축 및 산업 분야를 각각 들 수 있다.

\section{2) 국가별 중점협력분야 사업 및 예산 평가}

2017년도 KOICA 예산을 바탕으로 중점협력대상 24개국의 사업 수와 예산을 정리한 결과는

6) 국가별로 복수의 분야 선택이 가능한 점을 감안하여, 중복을 제외하고 전체 중점협력국 수를 기입하였다. 
아래와 같다. 종합적으로 살펴보면, $\mathrm{KOICA}$ 의 중점협력국 대상 사업 (프로젝트 및 개발컨설팅) 규모는 총 204건, 연간 예산 1,996 억 수준이다. 그중 국가별 중점분야에 해당하는 사업 건수는 141 건이며, 예산 기준으로는 1,411 억 원이다. 이를 비율로 환산하면 각각 $69 \%, 71 \%$ 로 사업 수와 예산 비중이 모두 목표치인 $70 \%$ 에 근접하였다.

국가별로는 총 12 개국, $50 \%$ 의 국가가 $70 \%$ 이상의 예산을 중점분야에 할당하였다. 동시에 여전히 절반의 국가가 목표달성 가능성 '낮음' 이하에 머물러있다는 점도 눈길을 끈다.

〈표 6〉 중점분야 예산 집중도에 따른 중점협력국가 분류 및 현황

(단위: 건, 백만 원)

\begin{tabular}{|c|c|c|c|c|c|}
\hline \multirow{4}{*}{$\begin{array}{c}\text { 목표달성 } \\
\text { 가능성 }\end{array}$} & \multirow[t]{2}{*}{ 해당 국가 } & $\begin{array}{c}\text { 전체 사업 수 } \\
\text { (A) }\end{array}$ & $\begin{array}{c}\text { 중점분야 } \\
\text { 사업 수(B) }\end{array}$ & $\begin{array}{l}\text { 전체 예산 } \\
\text { (C) }\end{array}$ & $\begin{array}{l}\text { 중점분야 } \\
\text { 예산 (D) }\end{array}$ \\
\hline & & \multicolumn{2}{|c|}{$\left(B / A^{*} 100\right)$} & \multicolumn{2}{|c|}{$\left(\mathrm{D} / \mathrm{C}^{*} 100\right)$} \\
\hline & \multirow{2}{*}{ 합계 } & 204 & 141 & 199,576 & 141,083 \\
\hline & & \multicolumn{2}{|c|}{$69 \%$} & \multicolumn{2}{|c|}{$71 \%$} \\
\hline \multirow{6}{*}{$\begin{array}{c}\text { 높음 } \\
(100 \%)\end{array}$} & \multirow{2}{*}{ 인도네시아 } & 9 & 9 & 4,624 & 4,624 \\
\hline & & \multicolumn{2}{|c|}{$100 \%$} & \multicolumn{2}{|c|}{$100 \%$} \\
\hline & \multirow{2}{*}{ 가나 } & 5 & 5 & 2,738 & 2,738 \\
\hline & & \multicolumn{2}{|c|}{$100 \%$} & \multicolumn{2}{|c|}{$100 \%$} \\
\hline & \multirow{2}{*}{ 세네갈 } & 5 & 5 & 5,475 & 5,475 \\
\hline & & \multicolumn{2}{|c|}{$100 \%$} & \multicolumn{2}{|c|}{$100 \%$} \\
\hline \multirow{4}{*}{5 개국 } & \multirow{2}{*}{ 파라과이 } & 6 & 6 & 4,653 & 4,653 \\
\hline & & \multicolumn{2}{|c|}{$100 \%$} & \multicolumn{2}{|c|}{$100 \%$} \\
\hline & \multirow{2}{*}{ 우즈베키스탄 } & 8 & 1 & 9,372 & 9,372 \\
\hline & & \multicolumn{2}{|c|}{$88 \%$} & \multicolumn{2}{|c|}{$100 \%$} \\
\hline \multirow{12}{*}{$\begin{array}{c}\text { 보통 } \\
\text { (70\% } \\
100 \%) \\
7 \text { 개국 }\end{array}$} & \multirow{2}{*}{ 네팔 } & 8 & 7 & 5,413 & 5,313 \\
\hline & & \multicolumn{2}{|c|}{$88 \%$} & \multicolumn{2}{|c|}{$98 \%$} \\
\hline & \multirow{2}{*}{ 모잠비크 } & 4 & 3 & 6,600 & 6,300 \\
\hline & & \multicolumn{2}{|c|}{$75 \%$} & \multicolumn{2}{|c|}{$95 \%$} \\
\hline & \multirow{2}{*}{ 에티오피아 } & 14 & 9 & 16,220 & 11,885 \\
\hline & & \multicolumn{2}{|c|}{$64 \%$} & & \\
\hline & 타자 1 아 & 6 & 4 & 9,352 & 6,850 \\
\hline & 진시니 & & & & \\
\hline & 아제라바이자 & 6 & 3 & 1,235 & 879 \\
\hline & & & & & \\
\hline & 페루 & 8 & 7 & 6,400 & 5,900 \\
\hline & 콜롬비아 & & & & \\
\hline
\end{tabular}




\begin{tabular}{|c|c|c|c|c|c|}
\hline \multirow{4}{*}{$\begin{array}{c}\text { 목표달성 } \\
\text { 가능성 }\end{array}$} & \multirow{4}{*}{ 해당 국가 } & $\begin{array}{c}\text { 전체 사업 수 } \\
\text { (A) }\end{array}$ & $\begin{array}{c}\text { 중점분야 } \\
\text { 사업 수(B) }\end{array}$ & $\begin{array}{c}\text { 전체 예산 } \\
\text { (C) }\end{array}$ & $\begin{array}{l}\text { 중점분야 } \\
\text { 예산 (D) }\end{array}$ \\
\hline & & \multicolumn{2}{|c|}{$\left(B / A^{*} 100\right)$} & \multicolumn{2}{|c|}{$\left(\mathrm{D} / \mathrm{C}^{*} 100\right)$} \\
\hline & & 6 & 5 & 3,871 & 3,080 \\
\hline & & \multicolumn{2}{|c|}{$83 \%$} & \multicolumn{2}{|c|}{$80 \%$} \\
\hline \multirow{9}{*}{$\begin{array}{c}\text { 낮음 } \\
(70 \% \sim ~ \\
60 \%)\end{array}$} & \multirow{2}{*}{ 르완다 } & 9 & 6 & 6,350 & 4,100 \\
\hline & & \multicolumn{2}{|c|}{$67 \%$} & \multicolumn{2}{|c|}{$65 \%$} \\
\hline & \multirow{2}{*}{ 캄보디아 } & 11 & 7 & 12,531 & 7,974 \\
\hline & & \multicolumn{2}{|c|}{$64 \%$} & \multicolumn{2}{|c|}{$64 \%$} \\
\hline & \multirow{2}{*}{ 방글라데시 } & 11 & 7 & 7,735 & 4,922 \\
\hline & & \multicolumn{2}{|c|}{$64 \%$} & \multicolumn{2}{|c|}{$64 \%$} \\
\hline & \multirow{2}{*}{ 필리핀 } & 15 & 12 & 15,366 & 9,971 \\
\hline & & \multicolumn{2}{|c|}{$80 \%$} & \multicolumn{2}{|c|}{$65 \%$} \\
\hline & \multirow{2}{*}{ 라오스 } & 13 & 6 & 12,850 & 8,042 \\
\hline \multirow[t]{7}{*}{ 8개국 } & & \multicolumn{2}{|c|}{$46 \%$} & \multicolumn{2}{|c|}{$63 \%$} \\
\hline & \multirow{2}{*}{ 미얀마 } & 12 & 8 & 17,000 & 11,490 \\
\hline & & \multicolumn{2}{|c|}{$67 \%$} & \multicolumn{2}{|c|}{$68 \%$} \\
\hline & \multirow{2}{*}{ 몽골 } & 3 & 2 & 3,742 & 2,278 \\
\hline & & \multicolumn{2}{|c|}{$67 \%$} & \multicolumn{2}{|c|}{$61 \%$} \\
\hline & \multirow{2}{*}{ 볼리비아 } & 6 & 4 & 6,450 & 4,250 \\
\hline & & \multicolumn{2}{|c|}{$67 \%$} & \multicolumn{2}{|c|}{$66 \%$} \\
\hline & 베트나 & 23 & 14 & 27,273 & 15,065 \\
\hline & 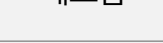 & & & & \\
\hline 매우 & 시리라카 & 7 & 4 & 3,468 & 1,718 \\
\hline (6)ㅈㅈ믐 & -20 & & & & \\
\hline 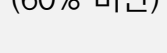 & 으가다 & 7 & 4 & 9,820 & 4,186 \\
\hline 4개국 & 1 & & & & \\
\hline & 파키스타 & 2 & 1 & 1,038 & - \\
\hline & - & & & & \\
\hline
\end{tabular}

출처: 국가별 CPS 및 $\mathrm{KOICA}$ 예산안을 바탕으로 저자 재구성

지역별로 살펴보면, 아시아 국가들은 대개 다양한 분야에서 많은 사업을 수행하다 보니, 중점 분야 예산 집중도가 낮은 경향이 있다. 이 결과는 아시아 지역에서 KOICA가 다양한 분야에 걸쳐 활발하게 활동해왔기 때문으로 이해할 수도 있지만, 다른 지역 대비 정치, 외교 등 다른 요소가 사업 발굴 과정에서 크게 영향을 미치고 있음을 방증한다고도 해석할 수 있다. 중동·중앙 아시아 또는 중남미 국가들은 상대적으로 중점분야 중심으로 사업을 수행하고 있는 것으로 나타난다. 특히, 중동·중앙아 지역 2 개국은 각각 예산 집중도 $100 \%, 71 \%$ 로 CPS에 따라 성실 
히 사업을 수행하고 있는 국가로 평가할 수 있다. 중남미 또한 볼리비아 1 개국을 제외한 나머지 3 개국이 목표달성 가능성 보통 이상 $(70 \% \sim 100 \%)$ 으로 분류되었다.

〈그림 3〉 목표달성도에 따라 분류한 지역별 현황 비교

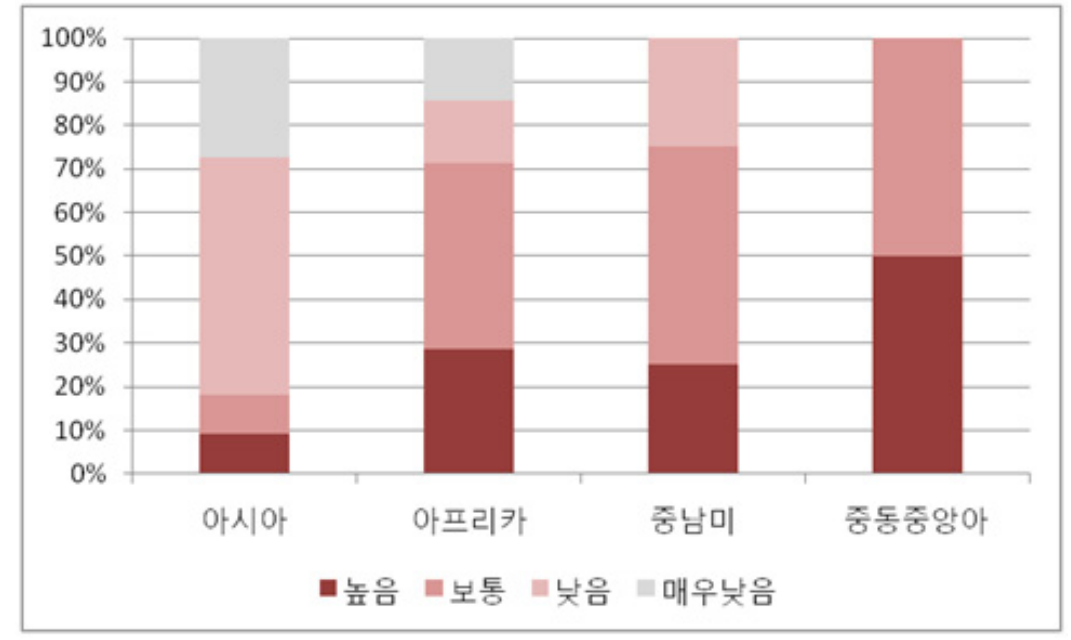

출처: 국가별 CPS 및 KOICA 예산안을 바탕으로 저자 재구성

\section{3. 목표달성 가능성에 따른 세부 국별 예산 분석}

\section{1) 목표달성 '높음' (100\%)}

현재 수행 중인 모든 사업이 중점분야와 일치하는 국가는 아시아의 인도네시아, 아프리카의 가나 및 세네갈, 중남미의 파라과이 등 총 4 개국이다. 이 국가들은 $\mathrm{CPS}$ 에 입각하여 중점분야 특화 사업을 집중해서 수행하고 있다고 평가할 수 있다. 반면, 우즈베키스탄도 예산 기준으로는 $100 \%$ 중점협력분야에 집중하고 있으나, 진행 중인 사업 목록에 비중점분야 사업 1 건이 포함되 어, 향후 중점협력 집중도에 다소간 변화가 예측된다.

구체적으로 인도네시아는 공공행정, 물관리, 교통, 환경보호 등 4 개 분야 9 건의 사업을 진행 중이며, 모든 사업, 예산이 중점협력분야에 해당함을 알 수 있다.

다음으로 가나의 중점분야는 보건, 지역개발, 교육, 에너지로 $\mathrm{KOICA}$ 는 네 가지 분야의 사업 을 고르게 진행하고 있다. 또한, 모든 사업, 예산을 중점협력분야에 집중하고 있다. 
파라과이 중점분야는 물관리 및 보건위생, 지역개발, 교통, 통신이지만, 통신을 제외한 세 가지 분야에 집중해서 사업이 진행 중이다. 중점협력분야가 무·유상을 아우르고 있다는 점을 감안한다면, 통신 분야는 대외경제협력기금(Economic Developement Cooperation Fund, 이하 $\mathrm{EDCF}$ )으로 대표되는 유상 중심의 원조가 진행되고 있을 것이라 예상해 볼 수 있으며, 이는 긍정적인 형태의 분업이라 평가할 수 있다. 앞서 살펴본 국가들과 마찬가지로 국가의 모든 사업 및 예산이 중점협력분야에 집중되어 있다.

세네갈은 중점분야인 물관리 및 보건위생, 교육, 교통, 지역개발 및 수산업 중에서 교통을 제외한 나머지 3 개 분야에 집중하고 있음을 아래 표에서 확인할 수 있다. 중점협력분야가 무·유 상원조를 아우르고 있다는 점에서 교통을 유상원조로 지원하고, $\mathrm{KOICA}$ 는 나머지 분야에 관심 을 기울인다면, 바람직한 형태의 분업이 될 것으로 평가할 수 있다.

끝으로 우즈베키스탄은 중점분야인 물관리 및 보건위생, 교육, 공공행정 외 비중점분야 사업 이 1 건 있기는 하지만, 예산만으로 평가할 때는, 중점분야에 집중하여 사업을 모범적으로 수행 하고 있음을 확인할 수 있다. 또한, 중점분야를 세 가지로 제한했다는 점에서, 적은 예산을 집중해서 효과적으로 사용하겠다는 의지를 함께 엿볼 수 있다.

\section{2) 목표달성 가능성 '보통' (70-100\%)}

다음은 예산 기준 $70 \%$ 이상을 중점협력분야에 집중하고 있는 국가들을 살펴보고자 한다. 앞서 언급한 4 개국과 달리, $\mathrm{CPS}$ 수립 이전부터 진행되던 사업이나, 수원국의 추가 수요에 의해 발굴된 일부 비중점분야 사업이 일부 있지만, 전반적으로 양호한 집중도를 보여주고 있다. 이 카테고리에 속하는 국가들의 한 가지 흥미로운 특징은 전체 중점분야 중 일부는 KOICA가 전혀 수행하고 있지 않은 분야라는 점이다. 추측건대 이러한 분야들은 중점분야 협의 과정에서 유상을 고려해서 안배되었으며, $\mathrm{KOICA}$ 는 그 분야들을 제외한 나머지에 집중하여 사업을 수행 한 결과, 어렵지 않게 목표를 달성한 것으로 보인다. 해당 국가는 아시아의 네팔( $88 \%, 98 \%$ 이상 각각 전체 사업 수 및 예산 대비 중점협력분야 비율) 1 개국, 아프리카의 모잠비크( $75 \%$, 95\%), 에티오피아(64\%, 73\%), 탄자니아(67\%, 73\%) 이상 3개국, 중남미의 페루(88\%, 92\%) 와 콜롬비아 $(83 \%, 80 \%)$ 이상 2 개국, 중동CIS 국가 중 아제르바이잔(50\%, $71 \%) 1$ 개국으로 총 7 개국이 이 카테고리에 속한다.

먼저 네팔은 네 가지의 중점분야 중 에너지를 제외한 물관리 및 보건위생, 교육, 지역개발 등 세 가지 분야 사업에 집중하고 있다. 다만, 비중점분야 사업 또한 1 건 진행 중이나, 전반적으 
로 매우 양호한 집중도를 보이고 있다.

모잠비크는 교통, 에너지, 물관리 및 보건위생, 교육을 중점분야로 선택하고 있다. 그러나 $\mathrm{KOICA}$ 는 그중에서도 물관리 및 보건위생, 교육이라는 두 개 분야에 집중하고 있음을 아래 표에서 확인할 수 있다. 중점협력분야가 무·유상을 아우르고 있다는 점에서 교통과 에너지를 유상원조로 지원하고, $\mathrm{KOICA}$ 는 나머지 분야에 관심을 기울인다고 판단한다면, 바람직한 형태 의 분업으로 이해될 수 있다.

에티오피아도 중점분야는 지역개발, 물관리 및 보건위생, 에너지, 교통 중 4가지이지만, $\mathrm{KOICA}$ 는 현재 지역개발과 물관리 및 보건위생 등 특정 분야에 집중하여 사업을 수행하고 있다. 앞서 살펴본 모잠비크의 사례와 마찬가지로 각자 비교우위를 따라 무·유상 간 효율적인 분업이 이루어질 것으로 기대되는 국가이다.

탄자니아 역시 유사한 형태를 보인다. 전체 중점분야는 물관리 및 보건위생, 교육, 교통, 에너지이지만, $\mathrm{KOICA}$ 의 사업은 물관리 및 보건위생과 교육에 집중하고 있다. 유상원조의 경우, 탄자니아의 교통과 에너지 분야에 많은 관심을 기울일 것으로 예측해 볼 수 있다.

이어서 중남미의 페루 또한 보건, 공공행정, 환경보호 등 세 가지 분야에 집중해서 사업을 추진하고 있으며, 교통 분야 사업은 현재 없다. 해당 국가에서 교통 분야는 주로 유상원조로 지원되었다는 점을 감안할 때, 비교적 분업을 원활히 수행하고 있는 것으로 평가할 수 있다. 한편, 비중점분야 사업도 한 건 진행되고 있지만 대체적으로 $\mathrm{KOICA}$ 의 사업과 예산 대부분이 중점협력분야에 집중되고 있다.

콜롬비아도 마찬가지로 4 대 중점분야를 명시하였음에도 불구하고, 주로 진행 중인 사업은 지역개발과 산업에 집중되어 있다. 현재 비중점분야 사업도 한 건 진행 중이지만, 예산 측면에서 는 $80 \%$ 이상을 중점협력분야에 집중하고 있어 보통 국가로 포함되었다.

끝으로 아제르바이잔 역시 위에서 언급한 여러 국가와 유사한 케이스이다. KOICA는 현재 물관리 및 보건위생, 통신 분야에 역량을 집중하고 있으며, 지역개발 및 교통 분야 사업은 진행 되고 있지 않음을 아래 표를 통해 확인할 수 있다. 다만 비중점분야의 사업도 3건이나 진행되고 있어, 향후 예산 측면에서 중점분야 집중도가 감소할 위험성이 있다.

\section{3) 목표달성 가능성 '낮음' $(60-70 \%)$}

비록 $70 \%$ 에는 미치지 못하였지만, 예산 기준 $60 \%$ 이상을 중점협력분야에 집중하고 있는 
국가들도 있다. 관심과 노력을 조금만 기울이면, 2020년도까지 예산 배정 목표달성이 가능할 것으로 기대된다. 대다수의 아시아 국가가 여기에 포함되는데, 캄보디아 $(64 \%, 64 \%)$, 필리핀 $(80 \%, 65 \%)$, 미얀마 $(67 \%, 68 \%)$, 방글라데시(64\%, 64\%), 라오스(46\%,63\%), 몽골(67\%, $61 \%)$ 이상 6 개국, 아프리카의 르완다 $(67 \%, 65 \%)$ 및 중남미의 볼리비아 $(67 \%, 66 \%)$ 각각 1 개국으로 총 8 개국이다.

가장 먼저 $\mathrm{KOICA}$ 는 캄보디아에서 교육, 지역개발, 교통, 물관리 및 보건위생 등 4 개 분야 11 건의 사업을 진행 중이다. 모든 중점분야에 걸쳐 다양한 사업을 수행하고 있으나, 예산이나 사업 수 모두 $70 \%$ 에는 미치지 못한다. 필리핀의 중점분야는 교통, 물관리 및 보건위생, 지역개 발, 재해예방으로 $\mathrm{KOICA}$ 는 4 개 분야 모두에서 여러 사업을 동시에 진행하고 있다. 사업 수를 기준으로 분류했을 때는 중점분야 집중도가 $70 \%$ 이상이지만, 예산 비중이 절반인 $57 \%$ 밖에 되지 않아 이 카테고리에 포함되었다.

한편, 미얀마의 중점분야는 교통, 에너지, 공공행정, 지역개발임에도 $\mathrm{KOICA}$ 는 통신을 제외 한 나머지 분야에 대한 사업을 진행하고 있다. 통신은 주로 유상으로 많이 지원된 분야라는 점을 감안하면, 유상원조기관과의 분업이 상대적으로 원활한 것으로 파악된다. 그러나 비중점분 야 사업이 다수 발굴되어, 사업 수 기준으로 12 건의 사업 중 8 건 만이 중점분야에 해당된다. 이는 2016년도 이전 비중점국가이던 당시, 국가 지원에 대한 큰 그림 없이 여러 분야 사업을 발굴한 결과인 것으로 예측된다.

방글라데시의 중점분야는 교육, 통신, 교통, 물관리 및 보건위생으로 4 개 분야 고르게 사업이 진행 중이다. 비중점분야 사업도 다수 추진되고 있어, 방글라데시의 중점분야 선정이 쉽지만은 않은 과제였으리라 추측된다.

라오스의 중점분야는 물관리 및 보건위생, 에너지, 교육, 지역개발로 에너지를 제외한 나머지 분야에 집중하여 사업을 추진하고 있다. 다만, 비중점분야 사업도 상당수 발굴되어 진행 중인 바, 향후 라오스 예산은 중점분야 집중도가 더 감소할 것으로 전망된다.

몽골에서 진행 중인 3건의 사업 중 두 건은 공공행정, 나머지 한 건은 비중점분야로 그 외의 중점분야인 교육, 물관리 및 보건위생, 교통 등 타 분야에 대한 사업 발굴이 상대적으로 부족하 다. 이는 예산 투입에서도 마찬가지의 경향을 보인다.

다음으로 르완다는 중점분야를 교육, 통신, 지역개발 등 세 가지만 설정하였으나, 실제로는 중점분야에 해당하지 않는 공공행정, 산업 등 타 분야 사업도 다양하게 추진 중임을 알 수 있다. 
끝으로 볼리비아의 중점분야는 보건, 교통, 에너지, 지역개발 등 4 개 분야임에도 교통과 에너 지 사업은 전혀 진행 중이지 않아 추가적인 사업 발굴 노력이 요구된다. 또한, 비중점분야 사업 도 두 건이나 진행 중인 사실을 고려할 때, 중점분야 집중도가 높지 않다는 점이 지적된다.

\section{4) 목표달성 가능성 '매우 낮음' ( $60 \%$ 미만)}

2018년 이후에 발굴되는 모든 신규 사업을 중점협력분야에 한정하는 등의 정책적 결단 없이 는 목표달성이 불가할 것으로 예상되는 국가도 있다. 예산 비중 집중도가 $60 \%$ 미만 국가그룹은 아시아의 베트남 $(61 \%, 55 \%)$, 스리랑카 $(57 \%, 50 \%)$, 파키스탄 $(50 \%, 0 \%)$ 등 3개국이며, 아프 리카의 우간다 $(57 \%, 43 \%)$ 또한 여기에 포함된다. 이들 국가는 추가 사업선정 및 예산 배정 시 각별한 주의와 변화가 요구된다.

$\mathrm{KOICA}$ 는 현재 베트남에서 현재 23건의 사업을 추진 중으로 중점협력국 중에서도 가장 사업 수가 많은 국가가 바로 베트남이다. 베트남의 중점분야는 공공행정, 교통, 보건, 교육이지 만, $\mathrm{KOICA}$ 는 그밖에도 9 건 이상의 타분야 사업을 추진하고 있다. 따라서 예산 기준 중점분야 집중도는 55\% 수준에 머물고 있다.

스리랑카의 중점분야는 교육, 교통, 물관리, 지역개발이지만, 실제 KOICA 사업은 교육과 교통에 국한되어 있다. 한편, 비중점분야 사업도 절반 정도를 차지하고 있어, 중점협력분야 집중도가 높지 않다.

파키스탄의 $\mathrm{CPS}$ 에 따르면 한국 정부는 물관리 및 보건위생, 에너지, 교통, 지역개발 등 4 개 분야 사업을 중점적으로 추진하게 되어있다. 그러나 KOICA의 2017년 사업계획을 살펴 보면 실제로는 물관리 및 보건위생 사업 1 건 및 비중점분야 사업 1 건, 총 2 건의 사업만이 진행되고 있다. 파키스탄은 $\mathrm{CPS}$ 와 $\mathrm{KOICA}$ 의 실질적인 사업 추진 사이에 상당한 괴리가 있는 국가이다.

마지막으로 우간다는 보건, 교육, 지역개발 사업 등 다양한 중점분야 사업을 수행하고 있었 으나, 비중점분야에 해당하는 사업 또한 다수 추진하고 있었다. 크지 않은 예산으로 다양한 분야의 사업을 수행하다 보니, 결국 예산이 중점분야에 집중하기 어려운 구조임을 확인할 수 있다. 


\section{III. 목표달성을 위한 중기(2017-2020) 국별 예산 산출}

\section{1. 산출방식}

제 3장에서는 2020년까지 CPS 목표를 달성하기 위해 4년간(2017-2020년) 투입되어야 하는

국별 예산 목표치를 산출하고자 한다. 즉, 24 개 중점협력국별로 중점분야 예산이 국가별 총예산 대비, 평균 $70 \%$ 이상이 되게 하는 최소한의 연도별 예산 배분안이다. 제시된 수치는 향후 3개년(2018-2020년) KOICA 중기 국별 예산 편성 가이드라인을 수립하는데 유용한 참고자료 로 활용될 수 있을 것이다.

먼저, 상수 a는 2017년도 국별사업에서 비중점분야 예산이 차지하는 비율이며, 아래와 같은 식으로 표현할 수 있다. 또한, 특정 국가의 중점분야 간 예산 비중은 2017년과 동일한 것으로 가정하였다.

$$
a=\frac{2017 \text { 년 국별사업 비중점분야 예산 }}{2017 \text { 년 국별사업 총 예산 }}
$$

이어서 상수 b는 4개년(2017 2020년)의 평균적인 연간 국별사업 예산 증가율을 의미한다. 아래 식을 바탕으로 도출한 b값은 KOICA의 지난 4개년(2014-2017년) 평균 증가율 $3.9 \%$ 와 동일한 것으로 가정하였다.

A1 : 최초 년도(2014년) 국별사업 예산 총액

A4 : 최종 년도(2017년) 국별사업 예산 총액

$\mathrm{n}:$ 기간(4년)

$\mathrm{b}$ : 평균 증가율

$$
\begin{aligned}
& A_{n}=A_{1}(1+b)^{n-1} \\
& (1+b)^{n-1}=\frac{A_{n}}{A_{1}} \\
& (1+b)=\left(\frac{A_{n}}{A_{1}}\right)^{\frac{1}{n-1}}-1
\end{aligned}
$$

이상의 a, b를 바탕으로, 4개년도(2017-2020년) 국가별 중점분야 예산 평균이 70\%가 되게 하는 비중점분야 예산의 증감률 $\mathrm{x}$ 는 아래 식과 같이 표현할 수 있다. 


$$
\begin{gathered}
a \times \frac{\sum_{n=1}^{4}(1+x)^{n-1}}{\sum_{n=1}^{4}(1+b)^{n-1}}=\frac{3}{10} \\
f_{(x)}=a \times \frac{\sum_{n=1}^{4}(1+x)^{n-1}}{\sum_{n=1}^{4}(1+b)^{n-1}} \\
f_{(x)}=\frac{3}{10} \\
\sum_{n=1}^{4}(1+x)^{n-1}=\frac{3}{10 a} \sum_{n=1}^{4}(1+b)^{n-1}
\end{gathered}
$$

이상의 식을 바탕으로 다음 장에서는 국가별 세부 예산 시나리오를 제시하고자 한다. 대상 국가는 2017년도 중점분야 예산 집중도가 $70 \%$ 이상인 12 개국을 제외하고, 목표달성 가능성이 '낮음' 또는 '매우 낮음'으로 분류된 12 개국으로 한정하였다. 그 결괏값은 목표달성 가능성에 따라 각각을 별도의 군으로 구분하였다.

\section{2. 중기 국별 예산 산출 결과}

\section{1) 목표달성 가능성 '낮음' 국가군}

먼저 목표달성 가능성이 낮다고 평가된 8개 국가를 살펴보고자 한다. 아래 표에 따르면, 방글라데시를 제외한 7 개 국가가 비중점분야 사업을 전년 대비 일정 비율 이상 감액하지 않는다 면, 4 개년도 중점분야 예산 평균 $70 \%$ 이상이라는 목표를 달성하기 어려울 것으로 예측된다. 이들 국가에 요구되는 연간 비중점분야 감액률은 평균 $6.38 \%$ 이며, 상세 내역은 아래와 같다.

〈표 7〉 연간(2018-2020년) 비중점분야 예산 감액 요구 비율 분석(1)

\begin{tabular}{c|c}
\hline 해당 국가 & 비중점분야 감액률 \\
\hline 캄보디아 & $7.31 \%$ \\
\hline 필리핀 & $6.56 \%$ \\
\hline 미얀마 & $1.06 \%$ \\
\hline 방글라데시 & - \\
\hline 라오스 & $10.74 \%$ \\
\hline 몽골 & $13.77 \%$ \\
\hline 르완다 & $7.03 \%$ \\
\hline 볼리비아 & $4.59 \%$ \\
\hline 평균 & $6.38 \%$ \\
\hline
\end{tabular}

출처: 국가별 $\mathrm{CPS}$ 및 $\mathrm{KOICA}$ 예산안을 바탕으로 저자 재구성 
지금부터는 표에서 도출한 국가별 비중점분야 예산 감액률을 바탕으로 2018-2020년 3개년 도의 예산을 산출하고, 국가별로 목표달성을 위한 예산 시나리오를 하나씩 짚어보고자 한다.

2017년 기준 캄보디아는 중점분야 사업 비중이 $64 \%$ 로 비교적 준수하나 목표에는 미치지 못한 다. 따라서 매년 최소 $7.31 \%$ 이상 비중점분야 사업을 줄여나가는 한편, 중점분야에 더 많은 예산을 투입해야 평균 70\%에 도달할 수 있다. 구체적으로 언급하자면, 비중점분야의 비율은 2018년 $31 \%, 2019$ 년 28\%로 점차 줄여나가되, 2020 년에는 $25 \%$ 까지로 축소되어야 한다.

2017년 예산상 필리핀은 중점분야 사업 비중이 65\%로 비교적 양호한 편이다. 하지만 최소 매년 $6.56 \%$ 이상 비중점분야 사업을 줄여나가는 한편, 중점분야에 더 많은 예산을 투입해야 목표치에 도달 가능하다. 모든 중점분야의 예산을 고르게 확대하는 한편, 비중점분야 예산은 2018년 32\%, 2019년 29\%로 점차 줄여나가되, 2020년에는 $26 \%$ 까지 축소되어야 한다.

미얀마는 2017년 기준 중점분야 사업 비중이 $68 \%$ 로 양호하다. 비중점분야 사업을 매년 $1.06 \%$ 만 감액하고, 늘어나는 예산을 전적으로 중점분야 중심으로 투입한다면 목표치 도달이 결코 어려운 일은 아니다. 중점분야예산을 전체에서 매년 $1 \%$ 정도씩만 확대해 나간다면 아래와 같이 목표달성이 가능할 것으로 예측된다.

방글라데시는 2017년 기준 중점분야 사업 비중이 $68 \%$ 로 매우 목표치에 근접하다. 따라서 국별 예산이 $3.9 \%$ 오른다고 가정했을 때, 비중점분야는 2017년 수준에서 유지하기만 한다면, 목표치에 무리 없이 도달할 수 있다. 다른 각도에서 살펴보자면, 연간 예산에서 중점분야가 차지하는 비율을 매년 $1 \%$ 씩 늘려나가는 것을 목표로 설정하였다.

라오스의 2017년 기준 중점분야 사업 비중은 $63 \%$ 로 목표치와 다소 거리가 있다. 따라서 현재 진행 중인 중점분야 외 사업 예산을 매년 $10.74 \%$ 이상 감소시키지 않는다면, 평균 $70 \%$ 이상을 중점분야에 집중한다는 CPS상의 목표는 결코 달성될 수 없다. 특히 앞서 살펴본 바와 같이 현재의 기조대로 중점분야보다 비중점분야에 더 많은 사업이 발굴된다면, 목표와 현실의 간극은 점점 더 커질 것이다. 따라서 신규 사업 발굴에 $\mathrm{KOICA}$ 본부 및 사무소의 각별한 관심과 의지가 요구된다.

몽골의 경우, 진행 중인 사업이 세 건에 불과함에도 불구하고 2017년 예산에 따르면 중점분야 외 사업 예산이 약 $40 \%$ 를 차지하였다. 결국, 매년 동 예산을 $13.77 \%$ 이상 감액하지 않는다면, 목표달성은 어려운 과제로 판단된다. 특히 CPS상 다양한 중점분야를 선정하고 있음에도 불구 하고, 현재 공공행정 분야를 제외하고 발굴되어 진행 중인 사업이 없다. 따라서 2018년 신규 사업을 적극적으로 발굴하되, 특히 교육, 물관리 및 보건위생, 교통 등 다른 중점분야에도 전방 
위적으로 관심을 기울이고 영역을 확대해나갈 필요가 있다.

르완다의 2017년 예산을 살펴보면, 중점분야 사업 비중이 $65 \%$ 수준으로 목표치보다는 낮지만, 상대적으로 양호한 예산 구조를 가지고 있다. 그러나 여전히 매년 $7.03 \%$ 이상을 감액하여야 중점분야 예산 비중을 $70 \%$ 까지 끌어올릴 수 있을 것으로 예상된다. 그러면 비중점분야 예산이 2018년 32\% 및 2019년 28\%까지 감소하고, 최종적으로 2020년에는 비중점분야에 25\%의 예산만 투입되는 것으로 예측되었다. 특히, 총 9건의 사업 중 2017년도 종료예정 사업이 7건인 점을 고려할 때, 2018년은 중점분야에 집중해서 사업을 추가 발굴할 수 있는 최적기인 것으로 판단된다.

$\mathrm{KOICA}$ 는 다양한 중점분야 중에서도 특히 보건에 집중하여 볼리비아 사업을 추진해 왔다. 그 결과, 2017년 기준으로는 보건 3건, 지역개발 1 건의 사업이 추진 중인 것으로 앞서 2 장에서 확인되었다. 다행스럽게도 비중점분야 사업 2건의 종료 예정연도가 2017년이다. 따라서 종료되 는 사업을 대신하여 중점분야 사업을 1건 이상 새롭게 발굴한다면 $70 \%$ 목표달성이 어렵지 않을 것으로 예상된다. 수치상으로는 매년 비중점분야 지원을 $4.59 \%$ 이상 감액하여야 하는 것으로 나타난다.

\section{2) 목표달성 가능성 '매우 낮음' 국가군}

2017년도 예산안을 근거로 살펴볼 때, 목표달성 가능성이 매우 낮은 것으로 평가된 중점협력 국은 총 4 개국이다. 해당 국가들은 예산상 중점분야 예산이 $60 \%$ 에도 미치지 못한다. 해당 국가에 서 현재 진행 중인 비중점분야 사업들을 갑자기 중단시키거나 순연시키는 것은 어려운 일이다. 결국, 더 이상 비중점분야 사업을 추가 발굴하지 않는 것이 차선의 대책이다. 또한, 국가별로 연간 예산 실링이 높아진다면 추가로 중점분야 사업을 적극 발굴해서 반영할 필요가 있다. 4 개국 은 평균적으로 비중점분야 예산을 매년 절반 수준으로 대폭 감소시켜 나가야만, 예산 평균 $70 \%$ 이상이라는 목표를 이룰 수 있을 것으로 보이며, 국가별 상세 내역은 아래 표와 같다.

〈표 8〉 연간(2018-2020년) 비중점분야 예산 감액 요구 비율 분석(2)

\begin{tabular}{c|c}
\hline 해당 국가 & 비중점분야 감액률 \\
\hline 베트남 & $22.49 \%$ \\
\hline 스리랑카 & $30.26 \%$ \\
\hline 파키스탄 & $78.43 \%$ \\
\hline 우간다 & $38.57 \%$ \\
\hline 평균 & $42.44 \%$ \\
\hline
\end{tabular}

출처: 국가별 CPS 및 $\mathrm{KOICA}$ 예산안을 바탕으로 저자 재구성 
베트남은 중점분야 외에도 다양한 사업이 진행 중인 국가이다. 이에 따라, 매년 $22.49 \%$ 이상 비중점분야 사업을 줄여나가지 않는 이상, 중점분야에 $70 \%$ 이상 사업을 집중하겠다는 $\mathrm{CPS}$ 의 공약은 현실성이 떨어지는 목표일 수밖에 없다. 많은 사업을 수행할 수 있다고 해서, 모든 분야의 사업을 다 추진하기보다는 $\mathrm{CPS}$ 중점분야에 집중하는 전략이 절실하다. 현재 $45 \%$ 인 비중점분야 예산을 2020 년에 $19 \%$ 까지 축소하기 위해서는 비중점분야 사업 발굴 중지, 중점 분야 사업 우선 수행 등 특단의 조치가 필요할 것으로 보인다.

스리랑카에서 현재 추진되는 사업만 살펴보면, KOICA가 2017년에서 2020년도 총 4개년도 평균 70\% 이상의 예산을 중점분야에 투입한다는 목표의 수준이 너무 높은 것이 아닌가 하는 다소 회의적인 생각이 들 수 있다. 하지만 2017년도에 종료되는 비중점분야 사업이 2건이나 있는 점을 고려한다면, 새로운 중점분야 사업 발굴과 추진에 기대를 걸어 볼 수 있다. 비중점분 야의 경우, 매년 최소 $30.26 \%$ 이상을 감액하고 나머지 국별 예산을 모두 교육 등 중점분야에 집중투자하여야 한다. 그래서 2017년 기준 50\%인 비중점예산을 2020 년에는 $15 \%$ 까지 낮추어 야 목표달성이 가능하다.

한편, 파키스탄을 2017년 예산만으로 평가한다면, $\mathrm{CPS}$ 를 작성한 의미가 무색할 만큼 사업목 록이 중점분야와 동떨어져 있다. 그러나 현재 진행 중인 2 건의 사업 중 비중점분야 사업 1 건이 2017년 종료예정임을 감안할 때, 2018년 사업 추진 시 중점분야인 물관리 및 보건위생, 에너지, 교통, 지역개발 등의 신규 사업을 적극적으로 추진한다면 목표달성이 불가능하지만은 않을 것으로 기대해 본다. 다만, 매년 $78.43 \%$ 이상의 비중점분야 예산을 감액하는 한편, 2018년도 예산 비중의 $79 \%$ 이상을 중점분야에 투입하고, 2019년 및 2020년에는 각각 $96 \%, 99 \%$ 를 중점분야에 집중하여야만 성취 가능한 상당히 도전적인 목표이다.

끝으로 우간다는 목표달성을 위해 현재 56억 이상 배정된 비중점분야 예산을 매년 최소 $38.57 \%$ 이상 감액하여야 한다. 현재 $57 \%$ 인 비중점분야 예산을 2020 년 기준 $12 \%$ 까지 단계적 으로 철저히 관리하여 줄여나가야만 달성 가능한 목표이다. 


\section{IV. 결론 및 정책 시사점}

지금까지 본고는 2017년 KOICA 사업 예산을 토대로 CPS 이행상황을 점검하고, 예산의 지역 및 섹터 편성에 대한 기준을 제시하였다. 다만, 이 연구가 보다 의미 있는 결과를 도출하기 위해서는 KOICA 내부적인 노력뿐만 아니라, 국내 ODA 거버넌스 전반에 대한 개선이 함께 이루어져야 할 것이다. 따라서 이번 장에서는 본 연구에서 논의된 결과를 바탕으로 제도 및 거버넌스 측면과 $\mathrm{KOICA}$ 기관 차원에서 각각의 정책적 제언을 살펴보고 결론을 맺고자 한다.

\section{1. 제도 및 원조 거버넌스 개선 시사점}

\section{1) 사업 발굴 및 예산 편성 시스템 개편}

$\mathrm{ODA}$ 사업 발굴과 예산 편성 시스템의 궁극적인 개선을 논하기 위해서는 다년도 예산 편성과 총사업비 및 국별협력사업 총 규모적 관점에 대한 접근이 선행되어야 한다는 지적을 피해갈 수 없을 것이다. 현실적인 접근 방법에 있어서 먼저 몇몇 외국 선진 원조기관들의 사례를 살펴봄 으로써 우리의 $\mathrm{CPS}$ 를 어떻게 예산 편성에 활용할 것인지에 대해 참고하고자 한다. 예를 들어 뉴질랜드의 경우, 전반적으로는 단년도 예산 시스템을 운영하지만, 국제개발협력사업의 특수성 에 대해 예산 당국을 설득하는 데 성공한 케이스이다. ODA 예산의 경우, 예산 당국이 향후 3 개년 예산 예측치를 선제시하며, 연간 예산은 집행기관이 한도 내에서 조정 가능하도록 유연성 을 부여하는 구조이다(한국국제협력단, 2017). 한편, 프랑스의 경우, 먼저 국가별 CPS에 도별 로 총 원조목표액을 정하고, 이 목표액을 다시 광범위한 분야별로 분류한다. 그런 다음 어느 원조집행기관이 어느 분야를 얼마나 담당할 것인가를 비교우위에 따라서 미리 정한다. 각 원조 기관은 이러한 계획에 근거하여 사업을 발굴하고 준비하도록 허용되며, 그 과정에서 중복된 사업은 자연스럽게 조정된다. 이후 최종적으로 국회는 다양한 기관이 발굴한 사업을 개별적으로 심의하는 대신, 분야별로 처리한다(김세원·김종섭·이영섭, 2013). 그 결과, 원조기관 간에 전문 성에 따른 분업과 협업을 자연스럽게 끌어낼 수 있으며, 지역 및 섹터별로 연계하여 전체 예산 파악이 가능해진다. 또한, 다년간 지출 한도를 미리 설정하여 국회의 동의를 받기 때문에, 결과 중심의 원조가 가능해지며, 원조사업의 예측 가능성도 높일 수 있다(장현식, 2001).

한 발짝 더 나아가 최근 기획재정부를 중심으로 논의되고 있는 융합예산은 특정 국가의 특정 개발목표를 지원하기 위해 다양한 부처의 예산이 통합적으로 배정, 관리되어야 한다는 점을 강조하고 있다. 그러나 현재의 사업 발굴 방식으로는 이미 발굴된 산발적인 사업을 예산상 
억지로 끼워 맞추는 형태가 될 수 있다는 우려가 크다. 이러한 우려를 불식하기 위해서는 CPS를 기준으로 분야는 확정하되, 국가별 세부 사업 자율성은 높이는 방향으로 예산 편성 시스템을 개편하는 것으로 고려해 볼 수 있다. 그 후에야 예산을 $\mathrm{CPS}$ 및 제 2 차 국제개발협력 기본계획 등 한국의 개발원조전략과의 연동이 유기적으로 이루어지고, 결국 효과적인 자원분배를 통해, 원조사업 목적을 적기에 달성할 수 있을 것으로 기대된다.

\section{2) CPS 수립 및 추진 방식 개선}

본 연구에서는 $\mathrm{CPS}$ 가 이행 시기 대비 뒤늦게 수립되었다는 점과 충분한 시행 기간 없이 중점협력국 리스트 및 $\mathrm{CPS}$ 가 교체되었다는 두 가지 측면이 1 기 $\mathrm{CPS}$ 의 근본적인 문제로 지적 되었다. $\mathrm{CPS}$ 를 적기에 수립하고 활용 기간을 충분히 보장하지 않는다면, $\mathrm{CPS}$ 를 아무리 훌륭하 게 작성한다 할지라도 활용도가 낮아질 수밖에 없기 때문이다.

한번 착수된 프로젝트는 대개 3 5년 이상 지속되며, 사업 수행 기간은 사업 효과성 제고를 위해 점차 확대되는 추세에 있다. 따라서 CPS와 사업 수행을 연계하기 위해서는 본격적으로 시행되기 전에 $\mathrm{CPS}$ 가 작성되고 공유되어야 하며, 한번 수립된 $\mathrm{CPS}$ 는 충분한 시간을 갖고 이행되어야 한다. 그렇지 않으면 신규 사업 발굴과 $\mathrm{CPS}$ 는 지속적으로 괴리될 수밖에 없을 것이다.

\section{3) 전체 원조수행기관에 대한 CPS의 구속력 강화}

원조사업의 분절화로 인해 $\mathrm{KOICA}$ 의 예산 비중은 매년 축소되는 반면, $\mathrm{EDCF}$ 를 중심으로 한 유상원조사업 및 여타 무상원조 수행기관 및 부처들의 역할과 목소리는 점점 커지고 있다. 2017년 기준 양자 원조에서 KOICA의 비중은 $39.4 \%$ 에 불과하다(한국국제협력단, 2016).

반면, 유상원조는 훨씬 규모가 큰데, 예를 들어 $\mathrm{EDCF}$ 의 '우즈베키스탄 국립아동병원 건립사 업의 2017년 예산은 327억 원이다. 이는 KOICA 우즈베키스탄 국별사업 전체 예산인 93.7억 의 약 3.5배에 해당하는 규모이다(국제개발협력위원회, 2016). 즉, 단위 사업의 규모를 고려할 때, 유상으로 지원되는 신규 프로젝트는 전체 국가 지원 포트폴리오에 미치는 영향도가 무상원 조보다 훨씬 크다. 따라서 $\mathrm{CPS}$ 기반 사업 추진 노력은 $\mathrm{KOICA}$ 만의 문제가 아니며, 유상원조기 관 및 타 무상원조기관이 다 함께 관심을 기울여 추진해야 할 과제로 인식되어야 한다.

이를 위해서는 먼저 원조조정기구이자 CPS 수립 및 관리 주체의 권한과 책임이 중요하게 다루어져야 할 것이다. 각 부처 및 정부 기관에서 $\mathrm{CPS}$ 의 중점협력분야와는 상관없이 경쟁적으 
로 발굴한 구체적인 사업을 형식적으로 조정하거나, 승인하는 역할에 머물지 말고 적극적으로 역할 을 규정하고 능동적으로 대처할 수 있게 되길 기대한다. 그렇지 않으면 여러 기관의 경쟁을 완화하기 위해 다수의 기관에 소규모 사업을 배분하는 방식으로 조정이 진행되어 오히려 원조 분절화를 가중 시키는 결과를 가져올 수 있다. 따라서 조정기관이 적극적으로 기관별 신규 사업이 CPS에 적합한지 를 면밀하게 검토하고 $\mathrm{CPS}$ 에 해당하지 않는 국가 및 분야 사업의 경우, 상의 기준점인 양자 사업의 $30 \%$ 를 근거로 발굴을 제한하는 등의 강력한 제재 조치도 검토해볼 수 있다.

$\mathrm{ODA}$ 예산 심의 과정에서도 $\mathrm{CPS}$ 의 지침 하에서 우리나라가 약속한 국가와 분야의 사업에 예산을 우선적으로 편성하고, $\mathrm{CPS}$ 에 기관별 원조 수행 전략을 일치시키지 않는 경우, 예산을 삭감하는 등 예산 심의 기구의 결단이 기대된다. 물론 복잡한 예산 편성 과정을 고려할 때 $\mathrm{CPS}$ 가 유일한 고려요소일 수는 없겠지만, 유관기관 간 긴밀한 협조와 실질적인 노력을 통하여 $\mathrm{CPS}$ 가 한국의 원조예산 편성 및 사업 발굴 과정의 주요 기제로 자리매김해 가길 바란다.

\section{2. $\mathrm{KOICA}$ 사업 추진 시사점}

\section{1) KOICA 국별사업 현황 점검 및 신규 사업 발굴 가이드라인}

본 연구는 중점협력국 지정 현황 및 $\mathrm{CPS}$ 상 중점지원 분야를 바탕으로 $\mathrm{KOICA}$ 사업 발굴의 우선순위와 분야를 설정한바, 그 결과가 실제 신규 사업 발굴 및 추진의 참고자료로 활용되길 기대한다. 더 나아가서는 향후 $\mathrm{KOICA}$ 예산 편성 및 요구과정에서 왜 특정 국가에 특정 분야 사업 예산이 더 투입되어야 하는지를 논리적으로 설명하는 근거로도 쓰일 수 있을 것이다.

연구 결과에 따르면 지역별 중점협력국 비중과 예산 배분의 연관성에도 불구하고, 4 개 지역별 로 중점협력국 예산 비중을 점검한 결과는 목표치인 $70 \%$ 에 미달하였다. 아시아태평양 지역이 중점협력국에 전체 지역 예산 중 $83 \%$ 를 배정한 것과 달리, 아프리카, 중남미, 중동·중앙아 등 나머지 지역의 중점협력국 예산 비중은 $60 \%$ 에도 미치지 못했다. 따라서 이들 지역은 예산 자체의 확대도 중요하지만, 특히 전체 지역 예산 대비 중점협력국 투입 예산 비중을 늘려나가는 방향으로의 변화가 기대된다. 역으로 사업 발굴 및 예산 편성 시 이들 지역의 비중점협력국 지원 비율은 단계적 축소가 병행되어야 할 것이다.

이어서, $\mathrm{KOICA}$ 가 수행 중인 다양한 사업이 CPS 상 중점협력분야를 얼마나 반영하고 있는 지를 살펴보면 전체 중점협력국의 중점협력분야 예산은 평균 $71 \%$ 로 목표치를 약간 상회하지만, 그중 $50 \%$ 인 아시아 9 개국(베트남, 캄보디아, 필리핀, 미얀마, 스리랑카, 방글라데시, 라오스, 
파키스탄, 몽골), 아프리카 2개국(르완다, 우간다), 중남미 1개국(볼리비아) 총 12 개국이 2017 년 예산 기준으로는 목표치에 미달하는 것으로 나타나 향후 신규 사업 발굴에 CPS에 대한 고려가 더 필요할 것으로 확인되었다.

\section{2) CPS의 활용 범위 확대}

봉사단, 연수 등도 $\mathrm{KOICA}$ 의 주요 사업의 일부임에도 불구하고, 이번 연구는 국별사업(프로 젝트 및 개발 컨설팅)에 한하여 예산 분석이 진행되었다. 왜냐하면, 국별사업을 제외한 나머지 사업 모달리티의 경우, 예산 체계에 국가와 섹터라는 두 가지 개념이 포함되어 있지 않기 때문이다. 예를 들어 봉사단의 경우는 예산의 구조가 모집선발, 교육파견, 현지적응, 현지활동, 사후관리 등 사업 추진 단계별로 분류되어 있고, 연수는 국가별, 다국가, 석사학위, 동창회 지원 등 연수의 형태로만 구분되어 있다(한국국제협력단, 2017). 따라서 현재 예산 체계에서 소위 말해 국별사업 으로 분류되어 있지 않은 여타 사업은 CPS에 기반하여 국가와 분야를 기획하기 어렵다.

예를 들어 국별사업(프로젝트 및 개발 컨설팅)의 규모가 작고 봉사단이나 연수 등 다른 사업 규모가 큰 국가의 경우, 예산 기획 당시에 고려되지 않았던 변수(예: 00국 $\triangle \triangle$ 분야 파견 봉사단, 00 국 $\triangle \triangle$ 분야 국별연수, 00 국 $\triangle \triangle$ 분야 국제기구 협력사업 등)에 의해 특정 분야의 실적이 증가 또는 감소할 수 있다.

따라서 중장기적으로는 현재 국별사업으로 분류되는 프로젝트와 개발컨설팅 이외의 다양한 사업 모달리티 역시 국가와 중점분야 중심으로 재편되는 것을 고려하길 권고한다. 예산은 국가 별, 분야별 투입 예산 중심으로 편성하되, 이후 개별 $\mathrm{KOICA}$ 지역사무소가 중점분야별로 사업 을 가장 효과적으로 수행할 수 있는 모달리티를 선택하여, 사업을 추진하는 방식으로 변화된다 면 특정 국가의 특정 개발목표를 보다 효과적으로 지원할 수 있을 것이라 기대한다.

\section{3) $\mathrm{CPS}$ 를 바탕으로 국별사업 시행계획 (가칭 $\mathrm{K}-\mathrm{CPS}$ ) 작성}

$\mathrm{CPS}$ 는 국가 전체의 $\mathrm{ODA}$ 전략을 담은 상위정책문서로 구체적인 사업명까지 담는 것은 현실적 어려움이 있다. 따라서 $\mathrm{CPS}$ 를 기본으로 하여 세부 사업과 예산 계획을 담은 국별사업 시행계획이 보완적으로 작성되어야 할 것이다. 아직 $\mathrm{KOICA}$ 가 추진 또는 계획 중인 사업 전체 포트폴리오조차 제대로 구성되어 있지 않은 중점협력국가도 있다는 점에서 쉽지 않은 작업이겠지만, 계획에 따른 실행의 중요성을 고려할 때, 연간 및 중장기로 작성되는 국별사업 시행계획이 긴요하다.

$\mathrm{K}-\mathrm{CPS}$ 의 작성 주체는 가능한 본부보다 현장이 되는 것이 바람직하다고 여겨진다. 앞서 
언급한 바와 같이, 본부의 조직은 사업형태별로 구성되어 있기 때문에 특정부서가 한 국가에서 진행 중인 다양한 사업 전부를 종합적으로 알고, 체계적으로 관리하기 어려운 상황이다. 설사 단순 취합 작업을 통해 리스트를 가지고 있다 해도, 국가의 필요에 따라 국가별 세부 실행계획을 세우는 일은 현장에서 수행하는 것이 훨씬 유리한 것으로 판단된다. 다만 추가적인 과업 수행에 따른 현업의 어려움은 인력 보강이나 관련 전문가 파견 등 본부의 적극적인 지원을 통해 해결될 수 있다. 사무소 주도로 실행계획을 작성하는 것을 시작으로 권한과 책임을 함께 이양하는 진정한 의미의 현장화의 첫걸음을 떼는 것이다. 그뿐만 아니라 작성과정에서도 수원국 정부와의 긴밀하게 협의가 가능하다는 점에서 $\mathrm{KOICA}$ 사업 추진에 대한 수원국의 안정감과 신뢰도를 높일 수 있으리라 기대한다.

끝으로 본 연구의 한계 및 향후 과제는 다음과 같다. 첫째로 본 연구는 한국의 전체 ODA 중 무상원조, 그중에서도 $\mathrm{KOICA}$ 의 예산만을 대상으로 분석을 수행하였다. 그 때문에 개별 국가 분석 과정에서 무·유상 간 중점분야 배분 현황 및 협업 과제가 일부 언급되긴 하였으나, 주로 $\mathrm{KOICA}$ 가 현재 수행하지 않는 분야에 한정되었다. KOICA가 수행 중인 분야의 경우에는 해당 분야가 무상으로 수행되는 것이 적절한지 또는 기관 간 경합, 중복의 가능성은 없는지 등에 대한 심층적인 분석은 본 연구의 범위에 포함되지 않았음을 밝혀둔다. 향후 KOICA뿐만 아니라 국제개발협력 종합시행계획에 포함되는 전 부처7)를 대상으로 CPS와 ODA 사업 예산 의 연관성을 분석하는 유사 연구를 시행한다면 한국 양자 원조사업의 전체 그림을 살펴볼 수 있다는 점에서 의미 있는 후속 연구가 될 수 있으리라 생각된다.

끝으로 아쉬운 부분은 $\mathrm{KOICA}$ 예산의 특수성이 연구에 일부 반영되지 못했다는 점이다. 국별사업 예산은 출연금과 이월예산으로 구성되나, 이번 연구는 2017년 신규 출연금에 한정하 여 분석되었다. 또한, 개발도상국에서 추진되는 사업 특성상, 다양한 변수에 의해 예산 전용이 빈번하다. 그 결과, 예·결산의 차이가 발생할 수 있음에도 불구하고, 그 차이에 관해서는 이번 연구에서 별도로 다루지 않은바, 향후 유사 연구 수행 시에는 그 점이 보완되어야 할 것이다.

이상의 몇 가지 한계에도 불구하고, 제도 및 거버넌스 측면과 $\mathrm{KOICA}$ 기관 차원에서 언급된 각각의 정책적 제언이 $\mathrm{KOICA}$ 내·외부에서 $\mathrm{CPS}$ 를 바라보는 관점의 변화를 일으키고, 제도개 선의 작은 원동력이 되길 바란다. 이러한 시도를 통해 $\mathrm{KOICA}$ 가 $\mathrm{CPS}$ 를 중심으로 사업을 수행하고, 궁극적으로 국내 다양한 ODA 수행기관에 모범이 될 뿐 아니라, 한국을 대표하는 무상원조기관으로서 입지를 확고히 하는데 긍정적인 영향력을 미치길 기대한다.

7) 2017년도 기준 총 42개 기관 (지자체 9개 포함)이 ODA 사업수행 (국제개발협력위원회, 2016) 


\section{참고문헌}

강주홍. 2013. “한국의 ODA예산 운영에 관한 비판적 고찰과 개선방안 연구." 『국제개발 협력』2013-3호:87-112.

경희대학교 산학협력단. 2015 . 『제 1 차 ODA 기본계획 평가 및 향후과제 연구』. 세종: 국무조정실.

국제개발협력위원회. 2010. 『제 7-1호. 국제개발협력 선진화 방안』. 제7차 국제개발협 력위원회 의결안건.

2014a. 『제 17-1호. '14년 국제개발협력 종합시행계획(안)』. 제17

차 국제개발협력위원회 의결안건.

. 2014b. 『제 19-1호. 국가협력전략 수립 발전방안』. 제19차 국제 개발협력위원회 의결안건.

2015.『제22-1호. 제2차 국제개발협력 기본계획(안)』. 제 22 차 국 제개발협력위원회 의결안건.

2016. 『제 28-3호. 중점협력국 대상 국가협력전략(15개국)(안)』.

제 28 차 국제개발협력위원회 의결안건.

국제개발협력평가소위원회. 2015. 『제 19-1호. 국가협력전략(CPS) 종료평가 결과

(안)』. 제 19 차 국제개발협력 평가소위원회 의결안건.

김세원 · 김종섭 · 이영섭. 2013. “주요 선진공여국의 중점협력국 운영 및 관리체계 사례 연구." 『ODA정책연구』13-4호.

박복영 · 곽재성 · 김용빈. 2015 『제 1 차 ODA 기본계획 평가 및 향후과제연구』. 세종: 국무조정실.

유웅조. 2015. “제2차 국제개발협력 기본계획 수립을 둘러싼 주요쟁점과 개선과제." 『이 슈와 논점』1036호.

이경민 · 박장호 · 김선혁. 2015. “공적개발원조 예산 과정의 절차적 정당성 : 한국의 제 1 기 중점협력국 선정을 중심으로." 『국제개발협력연구』

2016-7(2):79-117.

이계우 · 박찬용. 2005. 『베트남을 위한 중장기 원조사업계획』. 성남: 한국국제협력단. 이태주. 2014. “국가협력전략(CPS) 어떻게 가야하는가?” ODA Watch 45차 ODA 토크:

국가협력전략(CPS) 왜 아무도 모르는가? (2014.05.23., 서울시청 시민청)

장현식. 2001. 『국제협력사업의 프로젝트 사이클과 심사-원조기관과의 비교분석적인 측면에서』. 성남: 한국국제협력단. 
정유아. 2010. “국가지원전략 프로세스 정형화 방안." 『개발정책 포커스』 제 4호. 한국국제협력단. 『2017년도 KOICA 대외무상원조 사업계획』. 성남: 한국국제협력단. 『2017년도 예산(안)』. 성남: 한국국제협력단.

OECD. 2012. "Korea Development Assistance Committe (DAC) Peer Review." Paris: Organization for Economic Cooperation and Development (OECD) 
〈참고〉 국별 중기 예산 편성 시나리오

\section{(1) 캄보디아}

(단위: 백만 원)

\begin{tabular}{c|c|c|c|c|c}
\hline 분야 & 2017 & 2018 & 2019 & 2020 & 계 \\
\hline 교육 & 978 & 1,077 & 1,174 & 1,272 & 4,501 \\
& $8 \%$ & $8 \%$ & $9 \%$ & $9 \%$ & $8 \%$ \\
\hline 지역개발 & 2,256 & 2,483 & 2,709 & 2,934 & 10,383 \\
& $18 \%$ & $19 \%$ & $20 \%$ & $21 \%$ & $20 \%$ \\
\hline 교통 & 1,300 & 1,431 & 1,561 & 1,691 & 5,983 \\
& $10 \%$ & $11 \%$ & $12 \%$ & $12 \%$ & $11 \%$ \\
\hline 물관리 및 보건위생 & 3,547 & 3,904 & 4,260 & 4,614 & 16,325 \\
& $28 \%$ & $30 \%$ & $31 \%$ & $33 \%$ & $31 \%$ \\
\hline 중점분야 & 8,081 & 8,895 & 9,704 & 10,511 & 37,192 \\
& $64 \%$ & $68 \%$ & $72 \%$ & $75 \%$ & $70 \%$ \\
\hline 비중점분야 & 4,450 & 4,125 & 3,823 & 3,544 & 15,942 \\
& $36 \%$ & $32 \%$ & $28 \%$ & $25 \%$ & $30 \%$ \\
\hline 국별사업총계 & 12,531 & 13,020 & 13,527 & 14,055 & 53,133 \\
\hline
\end{tabular}

\section{(2) 필리핀}

(단위: 백만 원)

\begin{tabular}{l|c|c|c|c|c}
\hline \multicolumn{1}{c|}{ 분야 } & 2017 & 2018 & 2019 & 2020 & 계 \\
\hline 물관리 및 보건위생 & 3,546 & 3,885 & 4,224 & 4,564 & 16,219 \\
& $23 \%$ & $24 \%$ & $25 \%$ & $26 \%$ & $25 \%$ \\
\hline 지역개발 & 2,816 & 3,085 & 3,354 & 3,624 & 12,880 \\
& $18 \%$ & $19 \%$ & $20 \%$ & $21 \%$ & $20 \%$ \\
\hline 재해예방 & 3,609 & 3,954 & 4,299 & 4,645 & 16,507 \\
& $35 \%$ & $32 \%$ & $28 \%$ & $26 \%$ & $30 \%$ \\
\hline 중점분야 & 9,971 & 10,924 & 11,878 & 12,834 & 45,607 \\
& $65 \%$ & $68 \%$ & $72 \%$ & $74 \%$ & $70 \%$ \\
\hline 비중점분야 & 5,395 & 5,041 & 4,710 & 4,401 & 19,547 \\
& $35 \%$ & $32 \%$ & $28 \%$ & $26 \%$ & $30 \%$ \\
\hline 국별사업총계 & 15,366 & 15,965 & 16,588 & 17,235 & 65,154 \\
\hline
\end{tabular}


(3) 미얀마

(단위: 백만 원)

\begin{tabular}{l|c|c|c|c|c}
\hline \multicolumn{1}{c|}{ 분야 } & 2017 & 2018 & 2019 & 2020 & 계 \\
\hline 에너지 & 967 & 1,028 & 1,091 & 1,156 & 4,241 \\
& $6 \%$ & $6 \%$ & $6 \%$ & $6 \%$ & $22 \%$ \\
\hline 공공행정 & 3,537 & 3,759 & 3,989 & 4,227 & 15,512 \\
& $21 \%$ & $21 \%$ & $22 \%$ & $22 \%$ & $43 \%$ \\
\hline 지역개발 & 6,986 & 7,425 & 7,879 & 8,349 & 30,638 \\
& $41 \%$ & $42 \%$ & $43 \%$ & $44 \%$ & $30 \%$ \\
\hline 중점분야 & 11,490 & 12,212 & 12,958 & 13,732 & 50,392 \\
& $68 \%$ & $69 \%$ & $71 \%$ & $72 \%$ & $70 \%$ \\
\hline 비중점분야 & 5,510 & 5,451 & 5,393 & 5,336 & 21,691 \\
& $32 \%$ & $31 \%$ & $29 \%$ & $28 \%$ & $30 \%$ \\
\hline 국별사업총계 & 17,000 & 17,663 & 18,352 & 19,068 & 72,082 \\
\hline
\end{tabular}

\section{(4) 방글라데시}

(단위: 백만 원)

\begin{tabular}{l|c|c|c|c|c}
\hline \multicolumn{1}{c|}{ 분야 } & 2017 & 2018 & 2019 & 2020 & 계 \\
\hline 교육 & 2,582 & 2,724 & 2,873 & 3,027 & 11,206 \\
& $33 \%$ & $34 \%$ & $34 \%$ & $35 \%$ & $34 \%$ \\
\hline 통신 & 600 & 633 & 668 & 703 & 2,604 \\
& $8 \%$ & $8 \%$ & $8 \%$ & $8 \%$ & $8 \%$ \\
\hline 물관리 및 보건위생 & 2,110 & 2,226 & 2,347 & 2,473 & 9,157 \\
& $27 \%$ & $28 \%$ & $28 \%$ & $29 \%$ & $28 \%$ \\
\hline 중점분야 & 5,292 & 5,584 & 5,888 & 6,203 & 22,967 \\
& $68 \%$ & $69 \%$ & $71 \%$ & $72 \%$ & $70 \%$ \\
\hline \multirow{2}{*}{ 비중점분야 } & 2,443 & 2,453 & 2,463 & 2,472 & 9,831 \\
& $32 \%$ & $31 \%$ & $29 \%$ & $28 \%$ & $30 \%$ \\
\hline 국별사업총계 & 7,735 & 8,037 & 8,350 & 8,676 & 32,798 \\
\hline
\end{tabular}


(5) 라오스

(단위: 백만 원)

\begin{tabular}{l|l|l|l|l|l}
\hline \multicolumn{1}{c|}{ 분야 } & \multicolumn{1}{c|}{2017} & \multicolumn{1}{c|}{2018} & \multicolumn{1}{c}{2019} & \multicolumn{1}{c}{2020} & \multicolumn{1}{c}{ 계 } \\
\hline 교육 & 1,281 & 1,443 & 1,600 & 1,751 & 6,075 \\
& $10 \%$ & $11 \%$ & $12 \%$ & $12 \%$ & $11 \%$ \\
\hline 지역개발 & 2,611 & 2,941 & 3,260 & 3,569 & 12,382 \\
& $20 \%$ & $22 \%$ & $24 \%$ & $25 \%$ & $23 \%$ \\
\hline 물관리 및 보건위생 & 4,150 & 4,675 & 5,182 & 5,673 & 19,680 \\
& $32 \%$ & $35 \%$ & $37 \%$ & $39 \%$ & $36 \%$ \\
\hline 중점분야 & 8,042 & 9,060 & 10,042 & 10,994 & 38,137 \\
& $63 \%$ & $68 \%$ & $72 \%$ & $76 \%$ & $70 \%$ \\
\hline 비중점분야 & 4,808 & 4,291 & 3,830 & 3,419 & 16,348 \\
& $37 \%$ & $32 \%$ & $28 \%$ & $24 \%$ & $30 \%$ \\
\hline 국별사업총계 & 12,850 & 13,351 & 13,872 & 14,413 & 54,486 \\
\hline
\end{tabular}

(6) 몽골

(단위: 백만 원)

\begin{tabular}{l|c|c|c|c|c}
\hline \multicolumn{1}{c|}{ 분야 } & 2017 & 2018 & 2019 & 2020 & 계 \\
\hline 공공행정 & 2,278 & 2,626 & 2,951 & 3,259 & 11,113 \\
& $61 \%$ & $68 \%$ & $73 \%$ & $78 \%$ & $70 \%$ \\
\hline \multirow{2}{*}{ 중점분야 } & 2,278 & 2,626 & 2,951 & 3,259 & 11,113 \\
& $61 \%$ & $68 \%$ & $73 \%$ & $78 \%$ & $70 \%$ \\
\hline 비중점분야 & 1,464 & 1,262 & 1,088 & 939 & 4,753 \\
& $39 \%$ & $32 \%$ & $27 \%$ & $22 \%$ & $30 \%$ \\
\hline 국별사업총계 & 3,742 & 3,888 & 4,040 & 4,197 & 15,867 \\
\hline
\end{tabular}


(7) 르완다

(단위: 백만 원)

\begin{tabular}{l|c|c|c|c|c}
\hline \multicolumn{1}{c|}{ 분야 } & 2017 & 2018 & 2019 & 2020 & 계 \\
\hline 통신 & 1,550 & 1,703 & 1,856 & 2,009 & 7,119 \\
& $24 \%$ & $26 \%$ & $27 \%$ & $28 \%$ & $26 \%$ \\
\hline 교육 & 900 & 989 & 1,078 & 1,166 & 4,133 \\
& $14 \%$ & $15 \%$ & $16 \%$ & $16 \%$ & $15 \%$ \\
\hline 지역개발 & 1,650 & 1,813 & 1,976 & 2,139 & 7,578 \\
& $26 \%$ & $27 \%$ & $29 \%$ & $30 \%$ & $28 \%$ \\
\hline 중점분야 & 4,100 & 4,506 & 4,910 & 5,314 & 18,830 \\
& $65 \%$ & $68 \%$ & $72 \%$ & $75 \%$ & $70 \%$ \\
\hline \multirow{2}{*}{ 비중점분야 } & 2,250 & 2,092 & 1,945 & 1,808 & 8,095 \\
& $35 \%$ & $32 \%$ & $28 \%$ & $25 \%$ & $30 \%$ \\
\hline 국별사업총계 & 6,350 & 6,598 & 6,855 & 7,122 & 26,925 \\
\hline
\end{tabular}

(8) 볼리비아

(단위: 백만 원)

\begin{tabular}{l|c|c|c|c|c}
\hline \multicolumn{1}{c|}{ 분야 } & 2017 & 2018 & 2019 & 2020 & 계 \\
\hline 보건 & 3,450 & 3,736 & 4,026 & 4,321 & 15,534 \\
& $53 \%$ & $56 \%$ & $58 \%$ & $60 \%$ & $57 \%$ \\
\hline 지역개발 & 800 & 866 & 934 & 1,002 & 3,602 \\
& $12 \%$ & $13 \%$ & $13 \%$ & $14 \%$ & $13 \%$ \\
\hline 중점분야 & 4,250 & 4,602 & 4,960 & 5,324 & 19,136 \\
& $66 \%$ & $69 \%$ & $71 \%$ & $74 \%$ & $70 \%$ \\
\hline 비중점분야 & 2,200 & 2,099 & 2,003 & 1,911 & 8,213 \\
& $34 \%$ & $31 \%$ & $29 \%$ & $26 \%$ & $30 \%$ \\
\hline 국별사업총계 & 6,450 & 6,702 & 6,963 & 7,234 & 27,349 \\
\hline
\end{tabular}


(9) 베트남

(단위: 백만 원)

\begin{tabular}{l|c|c|c|c|c}
\hline \multicolumn{1}{c|}{ 분야 } & 2017 & 2018 & 2019 & 2020 & 계 \\
\hline 공공행정 & 3,100 & 3,884 & 4,549 & 5,125 & 16,657 \\
& $11 \%$ & $14 \%$ & $15 \%$ & $17 \%$ & $14 \%$ \\
\hline 교통 & 3,930 & 4,924 & 5,767 & 6,497 & 21,117 \\
& $14 \%$ & $17 \%$ & $20 \%$ & $21 \%$ & $18 \%$ \\
\hline 보건 & 650 & 814 & 954 & 1,075 & 3,493 \\
& $2 \%$ & $3 \%$ & $3 \%$ & $4 \%$ & $3 \%$ \\
\hline 교육 & 7,385 & 9,252 & 10,837 & 12,208 & 39,682 \\
& $27 \%$ & $33 \%$ & $37 \%$ & $40 \%$ & $34 \%$ \\
\hline 중점분야 & 15,065 & 18,874 & 22,107 & 24,904 & 80,950 \\
& $55 \%$ & $67 \%$ & $75 \%$ & $81 \%$ & $70 \%$ \\
\hline 비중점분야 & 12,208 & 9,463 & 7,335 & 5,686 & 34,692 \\
& $45 \%$ & $33 \%$ & $25 \%$ & $19 \%$ & $30 \%$ \\
\hline 국별사업총계 & 27,273 & 28,337 & 29,442 & 30,590 & 115,641 \\
\hline
\end{tabular}

(10) 스리랑카

(단위: 백만 원)

\begin{tabular}{l|c|c|c|c|c}
\hline \multicolumn{1}{c|}{ 분야 } & 2017 & 2018 & 2019 & 2020 & 계 \\
\hline 교육 & 1,718 & 2,383 & 2,893 & 3,296 & 10,290 \\
& $50 \%$ & $66 \%$ & $77 \%$ & $85 \%$ & $70 \%$ \\
\hline 중점분야 & 1,718 & 2,383 & 2,893 & 3,296 & 10,290 \\
& $50 \%$ & $66 \%$ & $77 \%$ & $85 \%$ & $70 \%$ \\
\hline \multirow{2}{*}{ 비중점분야 } & 1,750 & 1,220 & 851 & 594 & 4,415 \\
& $50 \%$ & $34 \%$ & $23 \%$ & $15 \%$ & $30 \%$ \\
\hline 국별사업총계 & 3,468 & 3,603 & 3,744 & 3,890 & 14,705 \\
\hline
\end{tabular}


(11) 파키스탄

(단위: 백만 원)

\begin{tabular}{l|c|c|c|c|c}
\hline \multicolumn{1}{c|}{ 분야 } & 2017 & 2018 & 2019 & 2020 & 계 \\
\hline 중점분야 & 0 & 855 & 1,072 & 1,154 & 3,081 \\
& $0 \%$ & $79 \%$ & $96 \%$ & $99 \%$ & $70 \%$ \\
\hline \multirow{2}{*}{ 중점분야 } & 0 & 855 & 1,072 & 1,154 & 3,081 \\
& $0 \%$ & $79 \%$ & $96 \%$ & $99 \%$ & $70 \%$ \\
\hline 비중점분야 & 1,038 & 224 & 48 & 10 & 1,321 \\
& $100 \%$ & $21 \%$ & $4 \%$ & $1 \%$ & $30 \%$ \\
\hline 국별사업총계 & 1,038 & 1,078 & 1,121 & 1,164 & 4,401 \\
\hline
\end{tabular}

(12) 우간다

(단위: 백만 원)

\begin{tabular}{l|c|c|c|c|c}
\hline \multicolumn{1}{c|}{ 분야 } & 2017 & 2018 & 2019 & 2020 & 계 \\
\hline 보건 & 2,136 & 3,440 & 4,324 & 4,954 & 14,854 \\
& $22 \%$ & $34 \%$ & $41 \%$ & $45 \%$ & $36 \%$ \\
\hline 교육 & 1,000 & 1,611 & 2,025 & 2,319 & 6,954 \\
& $10 \%$ & $16 \%$ & $19 \%$ & $21 \%$ & $17 \%$ \\
\hline 지역개발 & 1,050 & 1,691 & 2,126 & 2,435 & 7,302 \\
& $11 \%$ & $17 \%$ & $20 \%$ & $22 \%$ & $18 \%$ \\
\hline 중점분야 & 4,186 & 6,742 & 8,475 & 9,708 & 29,111 \\
& $43 \%$ & $66 \%$ & $80 \%$ & $88 \%$ & $70 \%$ \\
\hline 비중점분야 & 5,634 & 3,461 & 2,126 & 1,306 & 12,527 \\
& $57 \%$ & $34 \%$ & $20 \%$ & $12 \%$ & $30 \%$ \\
\hline 국별사업총계 & 9,820 & 10,203 & 10,601 & 11,014 & 41,638 \\
\hline
\end{tabular}

출처: 국가별 CPS 및 KOICA 예산안을 바탕으로 저자 재구성 